\title{
Use of Spatial Sampling and Microbial Source-Tracking Tools for Understanding Fecal Contamination at Two Lake Erie Beaches
}

By Donna S. Francy, Erin E. Bertke, Dennis P. Finnegan, Christopher M. Kephart, Rodney A. Sheets, John Rhoades, and Lester Stumpe

In Cooperation with the Northeast Ohio Regional Sewer District and Ohio Water Development Authority

Scientific Investigations Report 2006-5298 


\title{
U.S. Department of the Interior \\ DIRK KEMPTHORNE, Secretary
}

\author{
U.S. Geological Survey \\ Mark D. Myers, Director
}

U.S. Geological Survey, Reston, Virginia: 2006

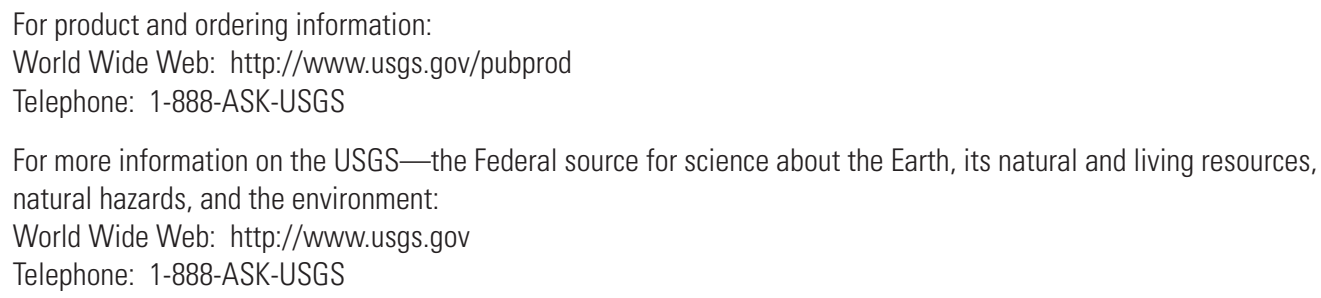

Any use of trade, product, or firm names is for descriptive purposes only and does not imply endorsement by the U.S. Government.

Although this report is in the public domain, permission must be secured from the individual copyright owners to reproduce any copyrighted materials contained within this report.

Suggested citation:

Francy, D.S., Bertke, E.E., Finnegan, D.P., Kephart, C.M., Sheets, R.A., Rhoades, John, and Stumpe, Lester, 2006, Use of spatial sampling and microbial source-tracking tools for understanding fecal contamination at two Lake Erie beaches: U.S. Geological Survey Scientific Investigations Report 2006-5298, 29 p. 


\section{Contents}

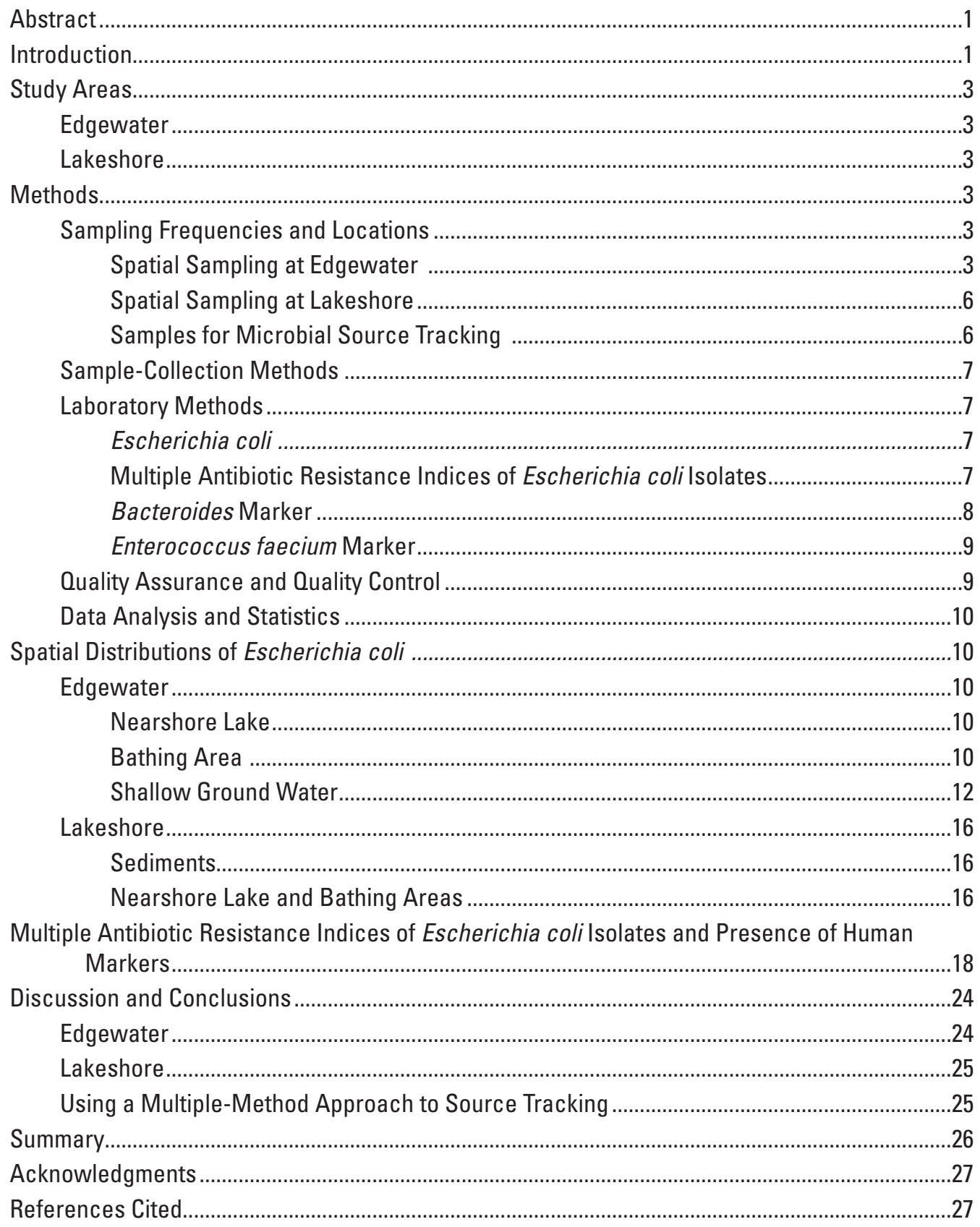




\section{Figures}

1. Maps showing location of Edgewater, Cleveland, Ohio: nearshore lake sampling sites and bathing-area and shallow ground-water sampling sites, 2003-2005.. 4

2. Map showing location of Lakeshore, Ashtabula, Ohio, and bathing-area, nearshore lake, and parking-lot sampling sites, 2004 and 2005

3. Photographs showing temporary piezometers with 0.5 -foot-long screens, installed at depths ranging from approximately 0.5 to 3.0 feet, at various intervals from the edge of water.

4. Photograph showing multiple antibiotic resistance testing on Luria-Bertani agar plates containing no antibiotic and one antibiotic

5.-10. Graphs showing:

5. Distribution of Escherichia coli concentrations at nearshore lake sampling sites in and around Edgewater, Cleveland, Ohio, 2003 and 2004, on 10 dry and 9 wet days

6. Average concentrations of Escherichia coli at Main and Middle Beach bathing-area sites, Edgewater, Cleveland, Ohio, 2005

7. Land surface, water levels, and Escherichia coli concentrations in shallow ground water and lake water at the east sampling location at Edgewater,

Cleveland, Ohio, 2004, in June, and July

8. Land surface, water levels, and Escherichia coli concentrations in shallow ground water and lake water at the west sampling location at Edgewater, Cleveland, Ohio, 2005, in June and July

9. Escherichia coli concentrations in shallow ground water and lake water at the west sampling location, Edgewater, Cleveland, Ohio, 2005, associated with distance to edge of water and $\mathrm{R}_{\mathrm{d}-1}$, lake level, wave height, and the water level in the piezometer 6 feet inland

10. Concentrations of Escherichia coli in water collected at nearshore and bathing-water sites at Lakeshore, Ashtabula, Ohio, on three days in 2004

11. Photograph showing stormwater runoff from a pipe draining the parking lot to the beach at Lakeshore, Ashtabula, Ohio, July 12, 2004.

12. Graph showing average concentrations of Escherichia coli at nearshore lake sites, Lakeshore, Ashtabula, Ohio, 2005

\section{Tables}

1. Escherichia coli concentrations in bed and parking-lot sediments in bathing-area, nearshore, and parking-lot sites at Lakeshore, Ashtabula, Ohio, 2004 and 2005.

2. Multiple antibiotic resistance (MAR) indices for samples collected at Edgewater and Lakeshore, 2005, and their relations to MAR indices of source samples.

3. Weather conditions, indicator concentrations, and results of microbial source tracking at bathing-water and other sites at Edgewater and Lakeshore, 2005. 


\section{Conversion Factors and Abbreviations}

\begin{tabular}{|c|c|c|}
\hline Multiply & By & To obtain \\
\hline \multicolumn{3}{|c|}{ Length } \\
\hline millimeter (mm) & 0.03937 & inch (in.) \\
\hline meter (m) & 3.281 & foot (ft) \\
\hline inch (in.) & 25.4 & millimeter (mm) \\
\hline foot (ft) & 0.3048 & meter $(\mathrm{m})$ \\
\hline mile (mi) & 1.609 & kilometer $(\mathrm{km})$ \\
\hline \multicolumn{3}{|c|}{ Volume } \\
\hline milliliter (mL) & 0.06102 & cubic inch $\left(\mathrm{in}^{3}\right)$ \\
\hline \multicolumn{3}{|c|}{ Mass } \\
\hline $\operatorname{gram}(\mathrm{g})$ & 0.03527 & ounce, avoirdupois (oz) \\
\hline
\end{tabular}

Temperature in degrees Celsius $\left({ }^{\circ} \mathrm{C}\right)$ may be converted to degrees Fahrenheit $\left({ }^{\circ} \mathrm{F}\right)$ as follows:

${ }^{\circ} \mathrm{F}=1.8\left({ }^{\circ} \mathrm{C}\right)+32$

Additional abbreviations

In addition to grams, masses are given in micrograms $(\mu \mathrm{g})$ and nanograms $(\mathrm{ng})$, which are $10^{-6}$ and $10^{-9}$ gram, respectively.

In addition to milliliters, volumes are given in microliters $(\mu \mathrm{L})$, which are $10^{-6}$ liter $\left(10^{-3}\right.$ milliliter).

Concentrations for certain polymerase-chain-reaction reagents are given as millimolar $(\mathrm{m} M)$ and micromolar $(\mu M)$.

Concentrations of bacteria are given in colony-forming units per 100 milliliters (CFU/100 mL), Most Probable Number per 100 milliliters (MPN/100 mL), colony-forming units per gram dry weight of sediment (CFU $\left./ g_{D W}\right)$, and colony-forming units per gram (CFU/g). 
This page is intentionally blank. 


\title{
Use of Spatial Sampling and Microbial Source-Tracking Tools for Understanding Fecal Contamination at Two Lake Erie Beaches
}

\author{
By Donna S. Francy, Erin E. Bertke, Dennis P. Finnegan, Christopher M. Kephart, Rodney A. Sheets, \\ John Rhoades ${ }^{1}$, and Lester Stumpe ${ }^{1}$
}

\section{Abstract}

Source-tracking tools were used to identify potential sources of fecal contamination at two Lake Erie bathing beaches: an urban beach (Edgewater in Cleveland, Ohio) and a beach in a small city (Lakeshore in Ashtabula, Ohio). These tools included identifying spatial patterns of Escherichia coli (E. coli) concentrations in each area, determining weather patterns that caused elevated E. coli, and applying microbial source tracking (MST) techniques to specific sites. Three MST methods were used during this study: multiple antibiotic resistance (MAR) indexing of $E$. coli isolates and the presence of human-specific genetic markers within two types of bacteria, the genus Bacteroides and the species Enterococcus faecium.

At Edgewater, sampling for $E$. coli was done during 2003-05 at bathing-area sites, at nearshore lake sites, and in shallow ground water in foreshore and backshore areas. Spatial sampling at nearshore lake sites showed that fecal contamination was most likely of local origin; $E$. coli concentrations near the mouths of rivers and outfalls remote to the beach were elevated (greater than 235 colony-forming units per 100 milliliters (CFU/100 mL)) but decreased along transport pathways to the beach. In addition, E. coli concentrations were generally highest in bathing-area samples collected at 1 - and 2 -foot water depths, midrange at 3-foot depths, and lowest in nearshore lake samples typically collected 150 feet from the shoreline. Elevated E. coli concentrations at bathing-area sites were generally associated with increased wave heights and rainfall, but not always. E. coli concentrations were often elevated in shallow ground-water samples, especially in samples collected less than 10 feet from the edge of water (near foreshore area). The interaction of shallow ground water and waves may be a mechanism of $E$. coli storage and accumulation in foreshore sands. Infiltration of bird feces through sand with surface water from rainfall and high waves may be concentrating $E$. coli in shallow ground water in foreshore and backshore sands.

${ }^{1}$ Northeast Ohio Regional Sewer District.
At Lakeshore, sampling for $E$. coli was done at bathingarea, nearshore lake, and parking-lot sites during 2004-05. Low concentrations of $E$. coli at nearshore lake sites furthest from the shoreline indicated that fecal contamination was most likely of local origin. High concentrations of $E$. coli in water and bed sediments at several nearshore lake sites showed that contamination was emanating from several points along the shoreline during wet and dry weather, including the boat ramp, an area near the pond drainage, and parking-lot sediments. Physical evidence confirmed that runoff from the parking lot leads to degradation of water quality at the beach.

MST samples were collected to help interpret spatial findings and determine whether sources of fecal contamination were from wastewater or bird feces and if a human-specific marker was present. MAR indices were useful in distinguishing between bird feces and wastewater sources because they were about 10 times higher in the latter. The results from MAR indices agreed with results from the two human-specific markers in some but not all of the samples tested. Bacteroides and enterococci human-specific markers were found on one day at Edgewater and two days at Lakeshore. On three days at Edgewater and two days at Lakeshore, the MAR index indicated a mixed source, but neither marker was found in bathing-water samples; this may be because bacterial indicator concentrations were too low to detect a marker.

Multiple tools are needed to help identify sources of fecal contamination at coastal beaches. Spatial sampling identified patterns in E. coli concentrations and yielded information on the physical pathways of contamination. MST methods provided information on whether the source was likely of human or nonhuman origin only; however, MST did not provide information on the pathways of contamination.

\section{Introduction}

To protect the health of swimmers, managers of beach recreational areas issue advisories or closings on the basis 
of standards for concentrations of bacterial indicator organisms. For freshwater beaches, Escherichia coli $(E$. coli) is the indicator most commonly used to assess recreational water quality. Collecting one or two daily samples for the enumeration of $E$. coli provides information on the occurrence but not the sources of fecal contamination; therefore, water-resource managers lack information on identified targets for effective mitigation measures.

Sources of fecal contamination that trigger most beach closings and advisories in the United States remain unknown (Natural Resources Defense Council, 2005). Frequently suspected sources include combined- and sanitary-sewer overflows; treated wastewater effluents; effluents from private sewage-treatment systems, including septic tanks; fecal pollution from birds, swimmers, or boaters; and stormwater runoff. Identifying and mitigating the source of fecal contamination to a particular beach is often complicated by the spatial and temporal variability of bacterial-indicator concentrations and the dynamic lake currents, weather patterns, and natural processes that affect these concentrations. In addition, many of the sources are of nonpoint origin and not easily identified.

Because of the complexity of coastal environments, a multiple-method approach seems practical at many beaches. At a California beach, for example, investigators used a three-tiered approach to discover that multiple sources of fecal contamination, including human sewage, affected recreational water quality (Boehm and others, 2003). The first two tiers documented the spatial and temporal variability of fecal-indicator bacteria pollution throughout the study area and in suspected sources. The third tier used microbial source tracking (MST) techniques and identified human-specific chemical and biological fecal indicators that corroborated earlier findings. At a bathing beach in northwestern Ohio, spatial patterns of E. coli and environmental factors were used in combination to identify sources of fecal contamination (Francy, Struffolino, and others, 2005). The results of the study implicated a ditch that discharges $250 \mathrm{ft}$ east of the beach as a principal source of $E$. coli, and not sources remote to the beach.

A wide range of techniques are available in the emerging field of MST to help identify sources of fecal contamination. Because all MST methods have distinct advantages and disadvantages (Meays and others, 2004), a single approach may not be adequate (Bower and others, 2005). Which methods are chosen for a study depend on the study objectives, the number of potential contamination sources, and the funds available (Meays and others, 2004). At coastal beaches along Lake Erie and elsewhere, the question is often whether the source is human or nonhuman, the nonhuman source being predominantly waterfowl.

Three MST methods were used during this study: multiple antibiotic resistance (MAR) indexing of $E$. coli isolates and the presence of human-specific genetic markers within two types of bacteria, the genus Bacteroides and the species
Enterococcus faecium. MAR is a phenotypic method that has been used to differentiate bacteria from different sources by use of antibiotics commonly associated with human and animal therapy. MAR indexing is based on the percentage of bacteria resistant to a panel of antibiotics. Because humans are exposed to antibiotics, the $E$. coli they harbor will likely be more resistant to antibiotics than those $E$. coli found in the gastrointestinal tracts of wildlife. MAR indexing of E. coli isolates has been shown to discriminate among nonhuman and human sources in the food industry (Krumperman, 1983) and in agriculture (Guan and others, 2002) and to characterize surface waters (Parveen and others, 1997; Kaspar and others, 1990; Webster and others, 2004), but it has not been used extensively at beaches. The other two methods detect genetic markers of organisms found in specific hosts. Detection of host-specific genetic markers circumvents the need for culturing bacteria and establishing an extensive host database and seems practical and cost effective for identifying sources at beaches. Bernhard and Field (2000a, b) identified host-specific genetic markers for Bacteroides, a genus of bacteria that are strict anaerobes (do not grow in the presence of oxygen) and make up a significant proportion of fecal bacteria in warmblooded animals. Molecular methods are used to target portions of the Bacteroides genetic material that are specifically found in Bacteroides from human sources. In other research, Bacteroides markers were found in association with suspected sources of contamination in Lake Michigan waters, including detections of the human marker at three out of seven bathing beaches (Bower and others, 2005). Another method targets a genetic marker that is a suspected virulence factor in Enterococcus faecium - the enterococcal surface protein (esp) — found in enterococci isolated from human sources. In a study of composited fecal and wastewater samples from Florida, Michigan, and Arizona, the Enterococcus faecium esp gene was detected in 97 percent of sewage and septic-system samples but was not detected in bird or other nonhuman fecal samples (Scott and others, 2005). It was detected in freshwater and simulated seawater samples when culturable enterococci were above 70 CFU/100 mL (Scott and others, 2005).

This report describes results of a study by the U.S. Geological Survey, Ohio Water Science Center (OWSC) in cooperation with the Northeast Ohio Regional Sewer District (NEORSD) and the Ohio Water Development Authority, investigating the use of various tools to identify potential sources of fecal contamination at two Lake Erie bathing beaches. Data on spatial patterns of E. coli at nearshore lake sites, in the beach area, at inland sites, and in shallow ground water led to identifying possible sources of fecal contamination. The spatial data were then used to select and target MST methods to specific areas, thereby making the best use of available time and resources. The source-tracking techniques used at Lake Erie beaches can be applied by managers in other coastal areas to address water-quality issues for local beaches. 


\section{Study Areas}

Studies were done at two Lake Erie beaches in northeast Ohio: Edgewater, in Cleveland, Ohio; and Lakeshore, in Ashtabula, Ohio.

\section{Edgewater}

Edgewater is an urban recreational area in Cleveland, Ohio (fig. 1A). Edgewater is between the Rocky and Cuyahoga Rivers, both of which receive effluents from wastewater-treatment plants and septic systems, and inputs from combinedsewer overflows (CSOs) and separate storm sewers. Water quality at Edgewater is also potentially influenced by local sources (the park and the immediate area shown on fig. $1 B$ ) including the Edgewater outfall, stormwater runoff from the park, pets and wildlife (waterfowl and raccoons), and discharges from long-abandoned storm sewers. Discharge from the Edgewater outfall consists of stormwater runoff and CSOs; it flowed once during the recreational season of 2004 (July 31) and twice during 2005 (June 10 and July 21). Other mechanisms of contamination may be release of accumulated $E$. coli from foreshore sands (sands infiltrated by lake water at some time during the season) and (or) resuspension of E. coli from bed sediments underlying bathing waters (Francy and Darner, 1998). Previous studies at Edgewater showed that E. coli concentrations in foreshore sands and lakebed sediments were as high as 3,000 and $300 \mathrm{CFU} / \mathrm{g}_{\mathrm{dw}}$, respectively (Francy and others, 2003). The Main Beach is a popular swimming area that includes $800 \mathrm{ft}$ of guarded beach (fig. $1 B$ ). The Middle Beach is unguarded, less often used by swimmers, and used by boaters and dog owners with their pets. A groin to the west and breakwater to the east of the Main Beach impede the flow of longshore currents. During 2004 and 2005, water-quality advisories were posted at Edgewater on 9 and 5 days, respectively (Ohio Department of Health, 2006).

\section{Lakeshore}

Lakeshore (fig. 2) is a popular bathing beach and recreational area in a small municipality. The bathing beach is adjacent to a paved parking lot and downgradient from a gravel parking lot. Potential sources of fecal contamination include a wastewater-treatment plant to the west of Pinney Dock and local sources. Local sources in the park include wildlife-mainly waterfowl, which frequent the beach and inland ponds - drainage from inland ponds, and runoff from parking lots and grassy areas. Other potential local sources include septic tanks and sanitary sewerlines that serve the small community uphill approximately $500 \mathrm{ft}$ south of the beach, as well as illegal discharges from boats. An overflow line drains a catchment that accumulates stormwater from this community and discharges into the lake near the west groin. Like that at Edgewater, the beach at Lakeshore is surrounded by groins and breakwaters that impede the flow of currents. During 2004 and 2005, water-quality advisories were posted at Lakeshore on 42 and 5 days, respectively (Ohio Department of Health, 2006).

\section{Methods}

Data were collected during the recreational seasons (May through September) of 2003, 2004, and 2005 to include a range of conditions: during dry, calm weather; after a light or heavy rainfall; and during increased wave heights.

E. coli concentrations were used to monitor recreational water quality. The Ohio bathing-water single-sample maximum of $235 \mathrm{CFU} / 100 \mathrm{~mL}$ was used as a benchmark to evaluate water quality in this report. For water-quality standards attainment, this standard cannot be exceeded in more than 10 percent of the samples collected in a 30-day period (Ohio Environmental Protection Agency, 2003). This standard has been used as a single-sample maximum for beach-notification decisions in Ohio, effective December 2005 (U.S. Environmental Protection Agency, 2004). Before December 2005, the geometric mean of $126 \mathrm{CFU} / 100 \mathrm{~mL}$ was used for beach-notification decisions in Ohio.

\section{Sampling Frequencies and Locations}

At Edgewater, NEORSD collected samples for spatial studies at nearshore lake sites in 2003 and 2004 and at bathing-area sites in 2004 and 2005; the USGS assisted with spatial studies at bathing-area sites and collected samples for shallow-ground-water studies in 2004 and 2005. At Lakeshore, the USGS conducted spatial sampling at bathing-area and nearshore lake sites in 2004 and 2005; parking-lot sites were included in 2005. Samples for MST were collected by the USGS in 2005.

\section{Spatial Sampling at Edgewater}

Water samples were collected at nearshore lake (fig. 1A) and bathing-area (fig. $1 B$ ) sites as follows:

- Eight nearshore lake sites (J-Q, about $150 \mathrm{ft}$ from the shoreline)_-13 days in 2003 and 6 days in 2004 by use of a boat

- Two bathing-area sites at Main Beach (C and F, 3-ft water depths) - Monday through Friday in 2003-05 as part of the daily beach monitoring program

- Four additional bathing-area sites at Main Beach (A, B, D, and E, 1- and 2-ft water depths) - 14 days in 2005

- Three bathing-area sites at Middle Beach (G, H, and I, 3-ft water depths)_-48 days during 2005 


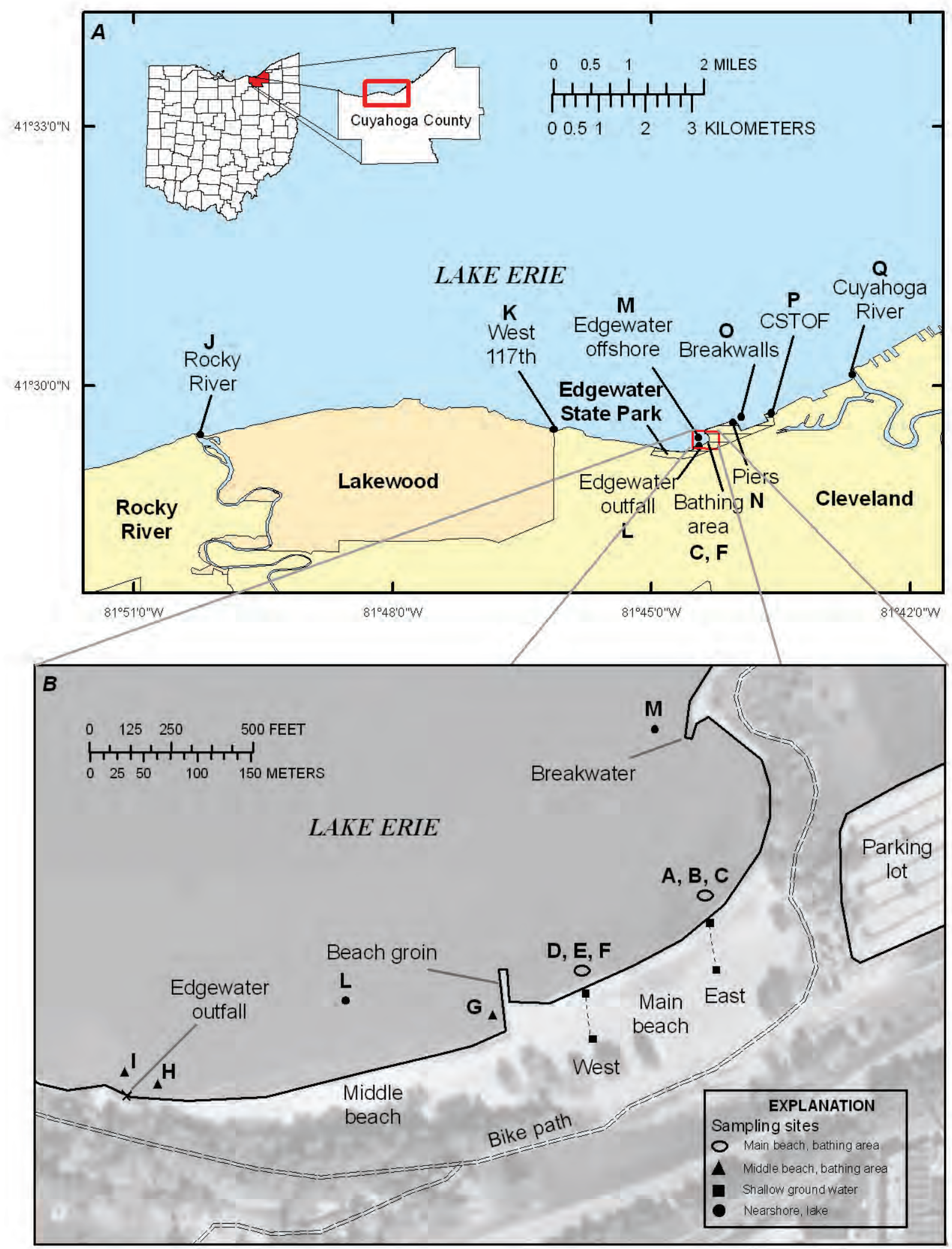

Figure 1. Location of Edgewater, Cleveland, Ohio. $A$, Nearshore lake sampling sites. $B$, Bathing-area and shallow ground-water sampling sites, 2003-2005. (CSTOF is Combined Sewer Treatment Overflow Facility. Bathing-area sites were defined by water depth ( 3 feet) and not by physical location.) 


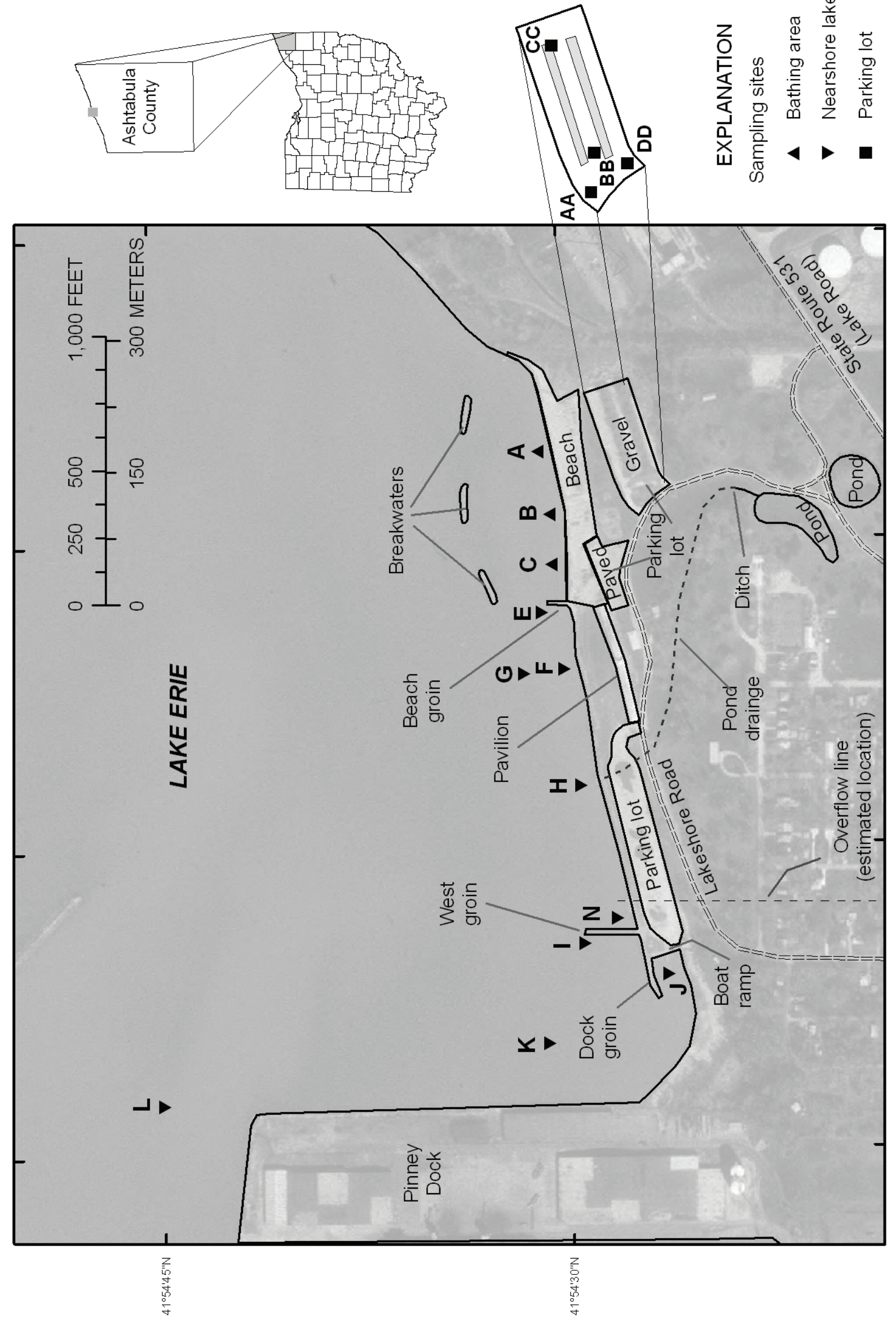

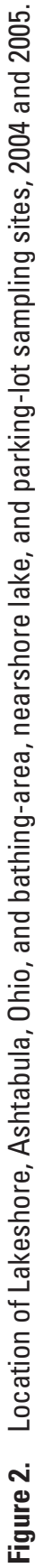


Short-term (one- or two-day) shallow-ground-water studies were done at the Main Beach at Edgewater during 2004 and 2005. A monthlong ground-water study was done in late summer 2005. For ground-water studies, temporary piezometers (fig. 3) were installed with 0.5-ft-long screens at depths ranging from approximately 0.5 to $3.0 \mathrm{ft}$. Piezometers were hand driven at the following intervals from the edge of water (the edge of water is the maximum wave run-up point) (in feet) (fig. $1 B$ ):

- June 30, 2004, east location-0, 25, 50, 75, 100

- July 28-29, 2004, east location-0, 3, 6, 9, 20, 40, 60, 80,100

- June 23, 2005, west location-0, 3, 6 (shallow), 6 (deep), 9, 20, 40, 60, 80, 100

- July 20-21, 2005, west location-0, 3, 6 (shallow), 6 (deep), 9, 20

- Aug. 16-Sept. 12, 2005, west location-6, 9

The 2-in.-internal-diameter piezometers were sterilized, driven to the desired depth by hand, and developed by mechanical surging (with a sterile surge pipe). To determine lake water level in the bathing area, a temporary stilling well also was installed at 2-3 ft water depths for all studies; the stilling well consisted of a pipe driven into the lake bottom with a screen open to lake waters. The relative elevation of the piezometers and stilling well were determined by conventional surveying techniques. Water levels in piezometers and the stilling well were measured with an electric tape.

\section{Spatial Sampling at Lakeshore}

Water or sediment samples were collected as follows (fig. 2):

- Three bathing-area sites (A-C, 3-ft water depths), water samples-Monday through Thursday in 2004 and 2005 as part of the beach monitoring program

- Three bathing-area sites $(\mathrm{A}-\mathrm{C})$, bed-sediment samples -7 to 11 days in 2004, depending on the site

- Eight nearshore lake sites (E-L), water and bed-sediment samples - 3 days in 2004 (some sites were not sampled on all 3 days)

- Three nearshore lake sites (F, H, and J), water samples-12 days in 2005

- Four parking lot sites (AA-DD), sediment-3 days in 2005

\section{Samples for Microbial Source Tracking}

Samples were collected for MST testing on four days during 2005: June 29, July 13, August 21, and September 1 at Edgewater; and June 28, July 14, August 15, and September 1 at Lakeshore. At both beaches, bird fecal samples and wastewater from the local treatment plant served as source samples. Secondary-treated wastewater samples were collected from the final clarifier before chlorination at the Southerly Wastewater Treatment Plant for Edgewater and at the Ashtabula
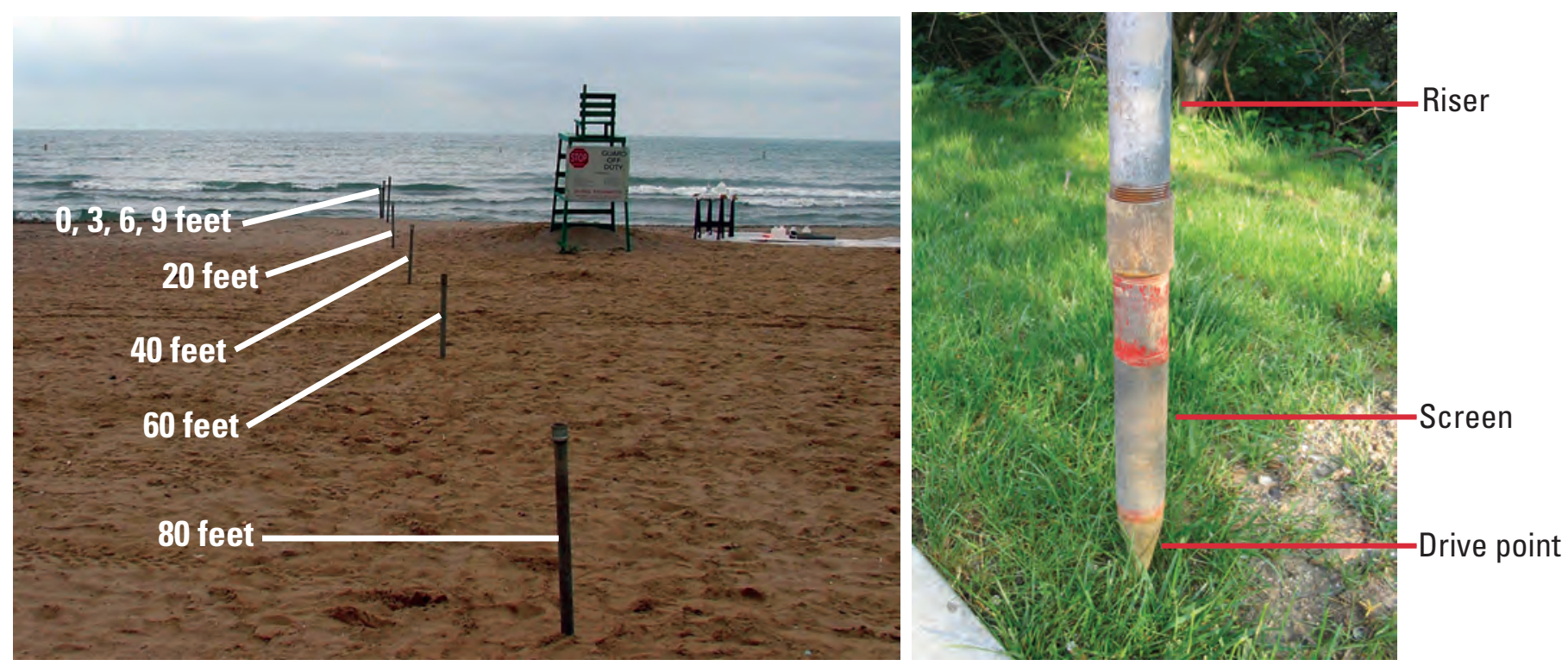

Figure 3. Temporary piezometers with 0.5 -foot-long screens, installed at depths ranging from approximately 0.5 to 3.0 feet, at various intervals from the edge of water. 
Wastewater Treatment Plant for Lakeshore. Bathing-water samples were collected for MST testing at both beaches on all four days. At Edgewater, samples for MST testing were also collected from shallow ground water on September 1. At Lakeshore, MST tests were also done on August 15 and September 1 on sediment samples from the gravel parking lot and water samples from additional sites that showed physical evidence of fecal contamination (sites I and N, fig. 2).

\section{Sample-Collection Methods}

Water samples from nearshore lake and bathing-area sites and from piezometers were collected into sterile polypropylene bottles. Water samples were collected at nearshore lake and bathing-area sites as grab samples from a boat, from the shore, or by wading to the sampling point (Myers and Wilde, 2003); samples were collected approximately $1 \mathrm{ft}$ below the water surface. Water samples from piezometers were collected by use of a peristaltic pump with sterile tubing. Before sampling, water levels in piezometers were measured with an electric tape that was sterilized with dilute bleach, neutralized with sodium thiosulfate, and rinsed with sterile water. Wave heights were measured by placing a marked survey rod in the water at the 3-ft water-depth sampling location for 1 minute, during which field crews noted the minimum and maximum heights. Lake currents in the bathing area were estimated visually by field crews.

Bed-sediment, parking-lot-sediment, and bird fecal samples were collected by use of sterile techniques. Bed and parking-lot sediments were collected into sterile, wide-mouth, 250-mL polypropylene jars. To collect bed sediments, field personnel reached to the lake bottom, opened the lid of the jar, and scooped the bottom sediments to obtain a sample. The lid of the jar was closed before surfacing. If the water was too deep to reach for a sample, the field crew lowered a clean and sterile Petite Ponar Grab sampler (Wildlife Supply Company, Buffalo, N.Y.) from a small boat and collected a bed-sediment sample per the manufacturer's instructions. Detailed sampling and decontamination procedures using the Petite Ponar Grab sampler are described elsewhere (Francy and others, 2003). Parking-lot-sediment samples were collected by scooping wet sediments into a jar. Three jars were collected from each sediment sampling point and composited before analysis. Bird fecal samples were collected from the sands at the bathing beaches. A fresh mass of bird fecal material was identified, and the top layer was removed with a sterile swab. From the center of the mass, a small piece of fecal material was removed with a second sterile swab and placed into a vial containing $100 \mathrm{~mL}$ of phosphate-buffered dilution water (U.S. Environmental Protection Agency, 2002a). These steps were repeated until materials were collected from 16 bird fecal samples into one vial.

\section{Laboratory Methods}

Water samples for E. coli were analyzed in local laboratories within 6 hours of collection. The NEORSD Analytical Services Laboratory analyzed nearshore lake and bathingwater samples from Edgewater for E. coli; the USGS assisted with the analysis of bathing-water samples and analyzed ground-water samples. At Lakeshore, all samples for $E$. coli were analyzed by the USGS. Samples for MST and sediments were sent to the USGS Ohio Water Microbiology Laboratory (OWML) in Columbus, Ohio, and processed within 24 hours of collection. All samples were kept on ice before analysis.

\section{Escherichia coli}

Lake-water samples, except for those in piezometer studies, were analyzed for $E$. coli by use of the modified mTEC membrane-filtration method (U.S. Environmental Protection Agency, 2002a). Because of high amounts of suspended materials, ground-water and sediment samples were analyzed for E. coli using Colilert Quantitray-2000 (Idexx Laboratories, Westbrook, Maine). Lake-water samples collected specifically for comparisons to piezometer samples were also analyzed using the Colilert Quantitray-2000 to expedite processing. For sediment samples, $20 \mathrm{~g}$ were aseptically removed from the composite jar and placed into a bottle containing $200 \mathrm{~mL}$ of phosphate-buffered dilution water; a second aliquot of sediment was removed to determine percent dry weight. The analyst placed the bottle on a shaker for 45 minutes, removed the bottle, allowed suspended materials to settle for 30 seconds, and decanted the liquid phase for analysis. Calculations were made as described in Francy and Darner (1998) to convert results to most-probable number per gram of dry weight sediment $\left(\mathrm{MPN} / \mathrm{g}_{\mathrm{DW}}\right)$.

\section{Multiple Antibiotic Resistance Indices of Escherichia coli Isolates}

Samples of bird feces, bathing water, wastewater, ground water, and parking-lot sediments were plated for E. coli on modified mTEC agar. Eighty isolated colonies were picked from the ideal count plates (20-80 colonies) from each source and environmental sample, whenever possible; otherwise nonideal count plates (those plates with $<20$ or $>80$ colonies) were used. Each colony was streaked for $E$. coli confirmation and isolation onto eosin methylene blue (EMB) agar and incubated at $36^{\circ} \mathrm{C}$ for 24 hours. From each EMB plate, one isolated colony was transferred to a well on a 96 -well microtiter plate containing Luria-Bertani (LB) broth; separate microtiter plates were used for each source. Controls on each plate included blank wells inoculated with LB broth only (negative control) and one well inoculated with E. coli ATCC 25922 (American Type Culture Collection, Manassas, Va.) as a susceptible organism. Every other column of wells on the microtiter 
plate was left as a blank column to prevent cross contamination. After overnight incubation at $36^{\circ} \mathrm{C}$, the microtiter plates were further processed for antibiotic resistance testing. A pin replicator was dipped into the microtiter wells and stamped onto a series of LB agar plates, each LB plate containing a different antibiotic (or different concentration of an antibiotic) and one plate containing no antibiotic. The antibiotics were those used in other studies (Parveen and others, 1997) and in previous tests of Lake Erie samples that showed the most discriminatory power between human and bird sources (data on file at the USGS OWSC). Final antibiotic concentrations were ampicillin, 10 and $20 \mu \mathrm{g} / \mathrm{mL}$; streptomycin, $25 \mu \mathrm{g} / \mathrm{mL}$; tetracycline, 25 and $50 \mu \mathrm{g} / \mathrm{mL}$; nalidixic acid, $25 \mu \mathrm{g} / \mathrm{mL}$; and sulfathiazole $1,000 \mu \mathrm{g} / \mathrm{mL}$. Two concentrations were used for some antibiotics to increase the likelihood that data were obtained even if spreading colonies grew on one of the plates. If growth on the antibiotic plate was approximately 50 percent or more of the growth on the control plate containing no antibiotics, the isolate was recorded as resistant (fig. 4). If there was no growth on the control plate, the isolate was removed from the dataset. Only one concentration from each antibiotic was used in the calculations, the concentration that had the smallest number of spreading colonies and the largest number of countable wells. MAR indices were calculated for isolates from each of the sources by the method of Kaspar and others (1990), as follows:
MAR index $=$ number of resistant isolates $/$ (number of antibiotics tested $\times$ total isolates tested)

\section{Bacteroides Marker}

Water samples were tested for the presence of a human marker from enteric anaerobic bacteria of the genus Bacteroides, as described in Dick and others (2005), according to the protocol originally described by Bernhard and Field (2000a). Water samples were filtered through a $0.22-\mu \mathrm{m}$-pore-size, 47-mm-diameter Durapore filter (Millipore, Billerica, Mass.). Parking-lot samples were not included because of the aerobic nature of the environment. Filters were loaded with measured volumes of sample to capacity; normally a total of $10-100 \mathrm{~mL}$ was filtered within 30 minutes. For each sample, a duplicate filter was processed. Immediately after filtration, each filter was aseptically folded to fit into a $15-\mathrm{mL}$ sterile plastic centrifuge tube and was stored at $-70^{\circ} \mathrm{C}$ until further analysis.

To prepare the filter for DNA extraction, a sterile razor blade was used to cut the filter into 1- to 3-mm strips. The filter strips were then processed by the PowerSoil DNA

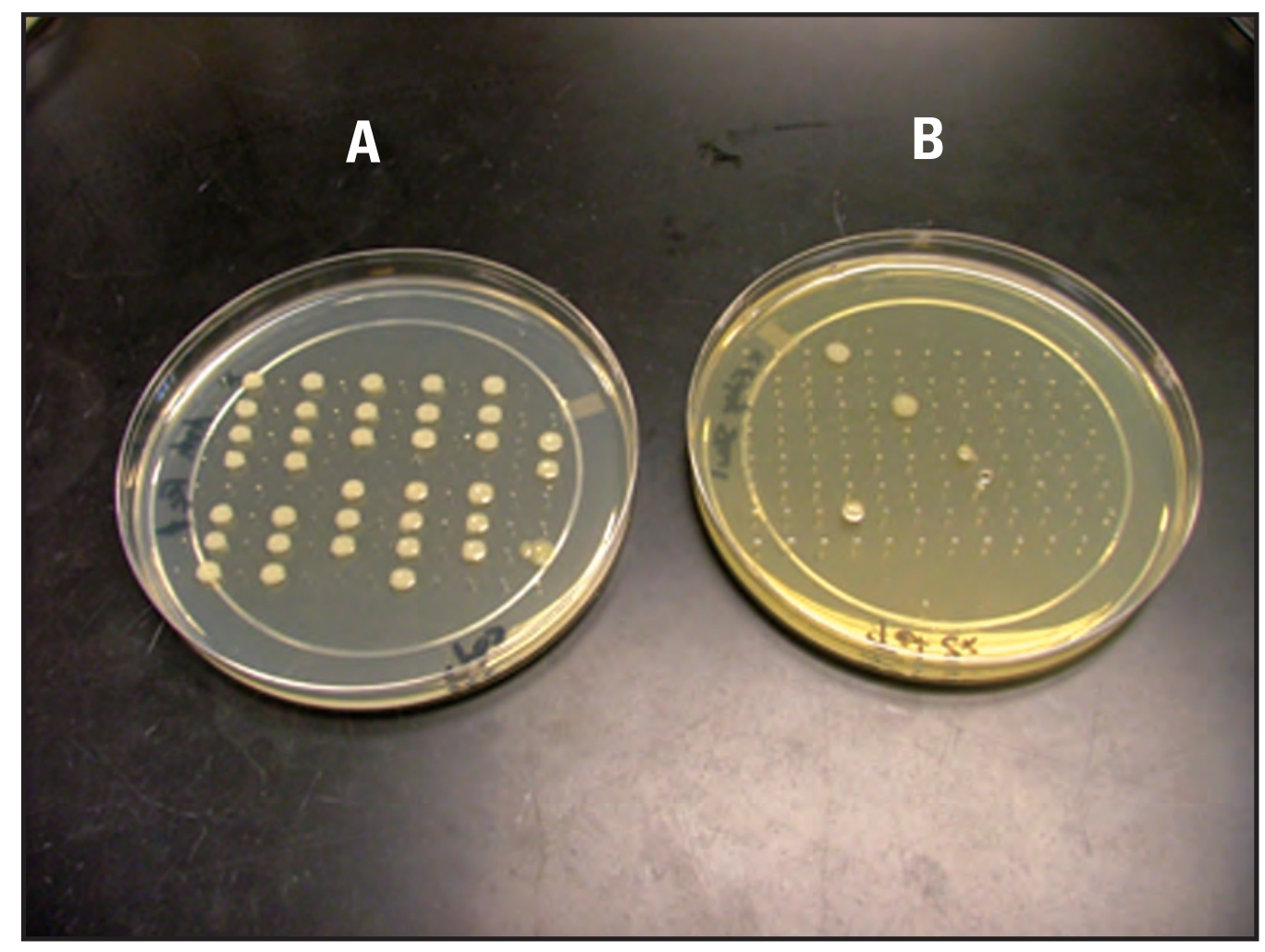

Figure 4. Multiple antibiotic resistance testing on Luria-Bertani agar plates containing $A$, no antibiotic (control plate), and $B$, one antibiotic. (The four colonies on the antibiotic plate that had at least 50 percent of the growth as compared to the control plate were recorded as resistant.) 
extraction and purification kit (MO BIO, Carlsbad, Calif.) per manufacturer's instructions. DNA extracts were quantified by use of a PicoGreen-based protocol (Molecular Probes, Eugene, Oreg.) and normalized to a consistent concentration of $2 \mathrm{ng} / \mu \mathrm{L}$.

The PCR was done in $25-\mu \mathrm{L}$ volumes containing $1 \mathrm{X}$ PCR buffer, $0.2 \mathrm{mM}$ of each of the four deoxyribonucleotides, 0.06 percent bovine serum albumin, $0.2 \mu \mathrm{M}$ of each primer, 1 unit of HotMaster Taq DNA polymerase (Eppendorf, New York, N.Y.), and $2 \mathrm{ng}$ of template DNA. Forward primers used for these analyses were Bac32 (5'-AAC-GCT-AGCTAC-AGG-CTT-3') for general Bacteroides and HF134 (5'GCC-GTC-TAC-TCT-TGG-CC-3') for the human-associated marker. Bac708 (5'-CAA-TCG-GAG-TTC-TTC-GTG-3') was used as the reverse primer in all reactions. Cycle conditions for the PCR were as follows: initial denaturation at $95^{\circ} \mathrm{C}$ for 3 minutes followed by 35 cycles of denaturation at $94^{\circ} \mathrm{C}$ for 60 seconds, annealing for 60 seconds, and extension at $72^{\circ} \mathrm{C}$ for 90 seconds. A final extension at $72^{\circ} \mathrm{C}$ for 90 seconds was used to terminate the reaction. The annealing temperatures used were $63^{\circ} \mathrm{C}$ for $\mathrm{HF} 134$ and $62^{\circ} \mathrm{C}$ for Bac32. PCR products were loaded onto a 7500 DNA chip and visualized by use of a BioAnalyzer (Agilent, Palo Alto, Calif.).

\section{Enterococcus faecium Marker}

Water and parking-lot sediment samples were tested for the presence of Enterococcus faecium human-specific esp marker (enterococci marker) according to the protocol originally described by Scott and others (2005). Samples were analyzed for concentrations of Enterococcus spp. by USEPA method 1600, membrane filtration with mEI agar (U.S. Environmental Protection Agency, 2002b). The filter containing the most discernible enterococci colonies from each sample (typically 100-300 colonies) was lifted, suspended in a centrifuge tube containing tryptic soy broth, vortexed, and incubated for 3 hours at $41^{\circ} \mathrm{C}$. This step was done to wash the bacteria from the filters and partially enrich the culture. After incubation, the broth culture was vortexed, and duplicate 1-mL aliquots were dispensed into separate microcentrifuge tubes. Each aliquot was then centrifuged for 5 minutes at $5,000 \times g$, the supernatant was decanted, and the remaining cell pellet was resuspended in $1 \mathrm{~mL}$ of tris-EDTA buffer. The cell suspensions were stored at $-70^{\circ} \mathrm{C}$ until further analysis.

DNA extraction was performed on sample cell suspensions by means of a slightly modified protocol of the UltraClean microbial DNA isolation kit (MO BIO, Carlsbad, Calif). Each cell suspension was centrifuged for 5 minutes at $5,000 \times g$, and the supernatant was decanted. The remaining cell pellet was resuspended in $300 \mu \mathrm{L}$ of MicroBead solution, and manufacturer's instructions were then followed for DNA extraction and purification. DNA extracts were stored at $-20^{\circ} \mathrm{C}$ until further analysis.

The PCR was done in $25-\mu \mathrm{L}$ volumes containing $1 \mathrm{X}$ PCR buffer, $0.2 \mathrm{mM}$ of each of the four deoxyribonucleotides, $0.3 \mu \mathrm{M}$ of each primer, and 1.25 U of HotMaster Taq DNA polymerase (Eppendorf, New York, N.Y.). The forward primer used in this study was 5'-TAT GAA AGC AAC AGC ACA AGT T-3'; the reverse primer was 5'-ACG TCG AAA GTT CGA TTT CC-3' (Scott and others, 2005). Cycle conditions for the PCR were as follows: initial denaturation at $95^{\circ} \mathrm{C}$ for 3 minutes, followed by 35 cycles of denaturation at $94^{\circ} \mathrm{C}$ for 1 minute, annealing at $58^{\circ} \mathrm{C}$ for 1 minute, and extension at $72^{\circ} \mathrm{C}$ for 1 minute. PCR products were separated on a 1.0 percent, high-resolution agarose gel, stained using SybrGreen I nucleic acid stain, and photodocumented under UV light. Each gel included several $1 \mathrm{Kbp}$ ladder wells that helped confirm the presence of the $680 \mathrm{bp}$ esp target. Gel images were exported into BioNumerics software (Applied Maths, Austin, Tex.) for final analysis.

\section{Quality Assurance and Quality Control}

Quality-assurance and quality-control (QA/QC) practices are considered an integral part of all data-collection activities. Field and laboratory protocols were distributed to all personnel to ensure that procedures were followed correctly and consistently. The USGS made several on site QA/QC checks of procedures performed by field and laboratory personnel throughout each recreational season, and corrective actions were taken as needed. Procedures for QA/QC laboratory practices are described in Francy, Bushon, and others (2005).

Field quality-control samples were collected to measure sampling and analytical variability or contamination potential. At least 10 percent of $E$. coli samples were field QC samples, including split replicates, interagency split replicates, and field blanks. Split replicates consisted of two samples collected by the same agency, each bottle analyzed twice. Interagency split replicates consisted of one bottle collected by NEORSD and one collected by the USGS concurrently at the same sampling point. Each bottle was analyzed twice, once by NEORSD and once by the USGS. Field blanks were used to measure contamination potential during sample collection and handling. To collect a field blank, 200-500 mL of sterile buffer was poured into the bottle under actual field conditions. The field blank was processed the same as a regular sample for $E$. coli or for Bacteroides or enterococci markers.

In the laboratory, filter blanks were included for at least every three E. coli samples (and every sample for Bacteroides or enterococci markers) to document that filtration equipment and buffered water were not contaminated. Positive-control reference cultures for $E$. coli were analyzed periodically. Positive-control reference cultures were pure cultures of $E$. coli ATCC 10798 (American Type Culture Collection, Rockville, Md.) prepared by the USGS and distributed to laboratory personnel by overnight mail. At the same time, personnel in the USGS laboratory plated the pure culture, and results were compared. Results from QC samples were carefully monitored, and retests and (or) corrective measures were taken when needed. The results from QC samples did not require removal of any data from the datasets. 
Positive-control DNA (Delaware, Ohio, wastewater influent sample) and negative-control DNA (Delaware, Ohio, cattle feces) were similarly processed for the presence of the Bacteroides and enterococci markers. The presence of the general Bacteroides marker (Bac32) was used as evidence that the PCR reaction was successful; in the absence of Bac32, a matrix spike was included. For the enterococci marker, matrix spikes were included for each environmental sample to identify any possible matrix inhibition. PCR reagent blanks were included to test for contamination of PCR reagents with amplifiable target DNA.

\section{Data Analysis and Statistics}

Analysis of variance (ANOVA) was used to compare more than two groups of data. For data that were not normally distributed, the nonparametric rank transform test was done. Contingency-table analysis was used to assess the relations between MAR indices and fecal source; chi-square distributions were used to evaluate results from contingency tests (Helsel and Hirsch, 2002, p. 378-382).

Lake-level data were obtained from National Oceanic and Atmospheric Administration (NOAA) station in Cleveland for Edgewater (NOAA ID 9063053) (National Oceanic and Atmospheric Administration, 2005a).

Rainfall data were compiled from National Weather Service stations at Hopkins International Airport for Edgewater and at Ashtabula County Airport for Lakeshore (National Oceanic and Atmospheric Administration, 2005b). These sites are 5.5 and $11 \mathrm{mi}$ inland from the Lake Erie shoreline, respectively. For 2005, local rainfall data for Lakeshore were available from a private source, located approximately $0.5 \mathrm{mi}$ east of Lakeshore along the shoreline. The relation between local rainfall and $E$. coli concentrations at Lakeshore was stronger than between $E$. coli concentrations and airport rainfall (data not shown), so local data were used when available. For 2005 at Edgewater, data were also obtained from a NEORSD-operated gage at John Marshall High School, $3 \mathrm{mi}$ inland from the Lake Erie shoreline; data from this site were used to augment data collected at the airport gage.

Two rainfall variables were used to aid in data interpretation. " $\mathrm{R}_{\mathrm{d}-1}$ " was the amount of rain, in inches, that fell in the 24-hour period (9 a.m. to 9 a.m.) preceding the day of sampling. Rainfall weighted 72 hours ("Rw72") included 3 days of rainfall with the most recent rainfall receiving the most weight, as follows:

$$
\mathrm{Rw} 72=\left(3 * \mathrm{R}_{\mathrm{d}-1}+2 * \mathrm{R}_{\mathrm{d}-2}+\mathrm{R}_{\mathrm{d}-3}\right)
$$

where $\mathrm{R}_{\mathrm{d}-1,1} \mathrm{R}_{\mathrm{d}-2}$, and $\mathrm{R}_{\mathrm{d}-3}$ were amounts of rain that fell in 24-hour periods 1 day, 2 days, and 3 days preceding sample collection, respectively.

\section{Spatial Distributions of Escherichia coli}

\section{Edgewater}

At Edgewater, data from nearshore lake sites were used to identify potential regional origins of fecal contamination (such as rivers or outfalls) and determine E. coli concentrations along transport pathways to the beach. Measurements of $E$. coli concentrations in the bathing area were used to assess spatial patterns and identify local contamination. The piezometer studies were done to determine E. coli concentrations in shallow ground water and determine if the interactions between ground water, precipitation, lake levels, and wave height could explain the source or mechanisms of transport of E. coli to the beach.

\section{Nearshore Lake}

Data from 2003 and 2004 at nearshore lake sites (fig. 1A) were grouped into two datasets (fig. 5): (A) 10 "dry" days when $\mathrm{R}_{\mathrm{d}-1}=0$ in., and $(B) 9$ "wet" days when $\mathrm{R}_{\mathrm{d}-1}>0.1$ in. On the dry days, average and median $E$. coli concentrations were highest at the mouth of the Rocky River (site J), low at other nearshore lake sites, and slightly higher in the Edgewater bathing area. The bathing-area samples were the average concentrations at sites $\mathrm{C}$ and $\mathrm{F}$ on the 19 days that samples were collected at nearshore lake sites. On wet days, average $E$. coli concentrations were very high at the mouths of the Rocky River (site J) and Cuyahoga River (site Q), decreased along transport pathways to Edgewater from site Q, were low at the Edgewater nearshore lake site (site M), but were elevated in the Edgewater bathing area. On wet days, median E. coli concentrations were above $235 \mathrm{CFU} / 100 \mathrm{~mL}$ in the bathing area and at sites J, P, and Q. Differences in E. coli concentrations between the Edgewater bathing area (sites $\mathrm{C}$ and $\mathrm{F}$ ) and the nearshore lake sites not near river mouths or treatment facilities ( due to water depth. The samples at $\mathrm{C}$ and $\mathrm{F}$ were collected at 3 -ft water depths within the bathing area; the other samples were collected at average depths ranging from $5 \mathrm{ft}$ (site L) to $19.6 \mathrm{ft}$ ( site O). The effect of water depth on E. coli concentrations was not investigated during this study.

\section{Bathing Area}

Spatial studies were done at Main and Middle Beach bathing-area sites in 2005 (fig. $1 B$ ). In order to simplify data presentation, samples collected from sites that were spatially similar, located at similar water depths, and generally had the same range of $E$. coli concentrations were pooled into three groups. 

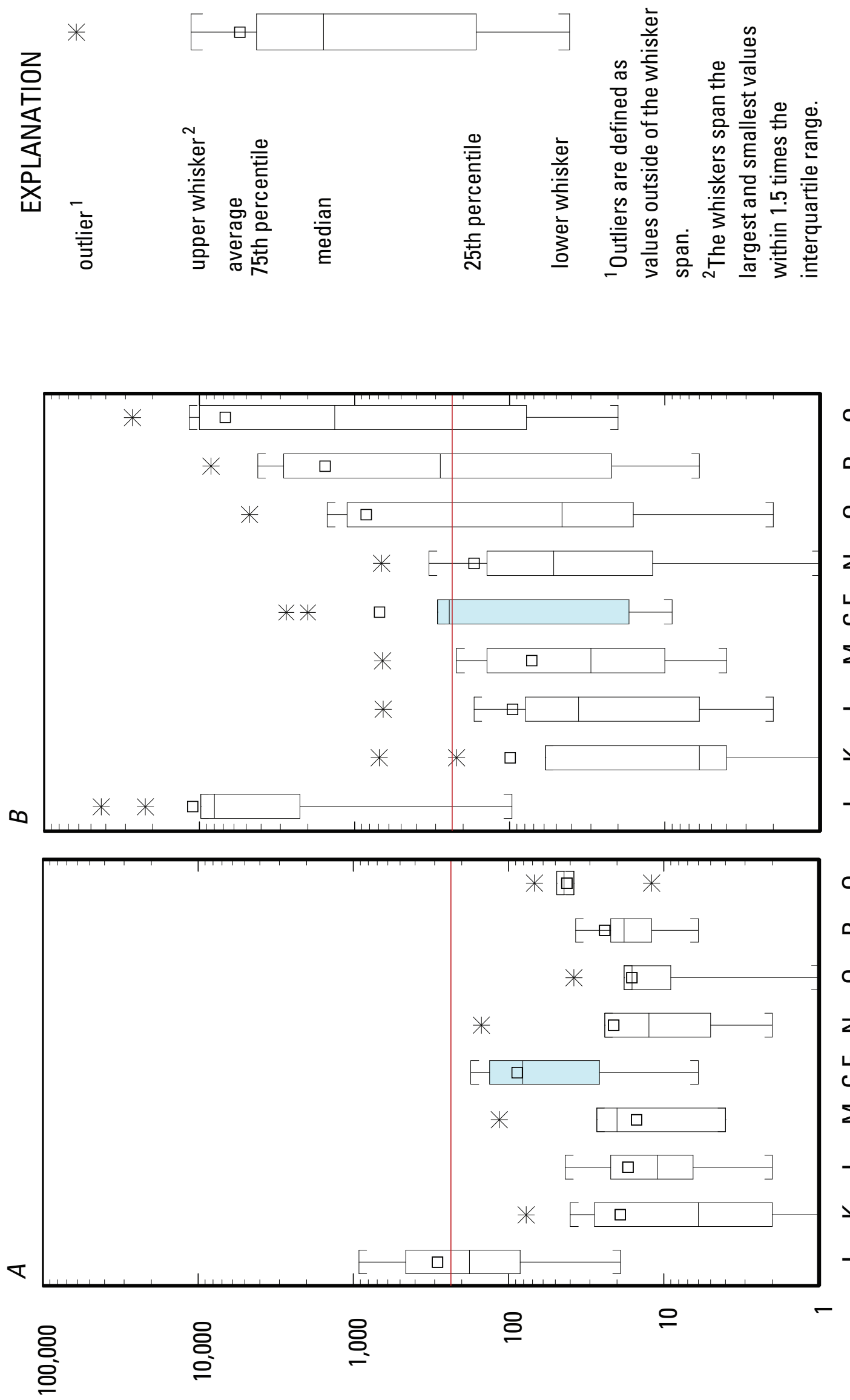

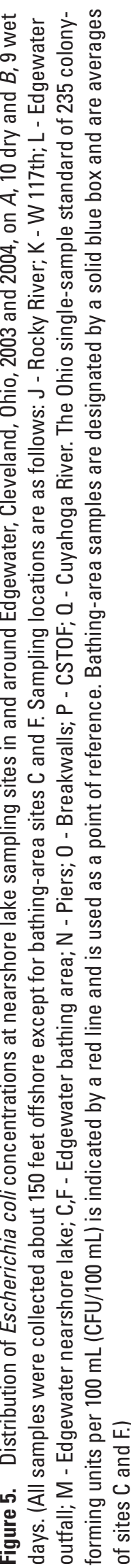


An average concentration was calculated for each day for the three groups (fig. 6): (1) Main Beach samples collected at 3-ft water depths (sites $\mathrm{C}$ and F, circles and solid connecting lines), (2) Main Beach samples collected at 1- and 2-ft water depths (sites A, B, E, and D, triangles), and (3) Middle Beach samples collected at 3-ft depths (sites G, H, and I, squares). Elevated average $E$. coli concentrations (greater than $235 \mathrm{CFU} / 100 \mathrm{~mL}$ ) were usually associated with increased wave heights and (or) rainfall, but not always (fig. 6). The patterns of E. coli concentrations were similar at the Main and Middle beaches; but on most days when concentrations were elevated, concentrations were higher at the Middle Beach than the Main Beach. Similarly, concentrations of E. coli collected at 1- and 2-ft water depths were often higher than those collected at 3-ft depths at the Main beach.

The Edgewater outfall, which discharges into the western end of Middle Beach, overflowed twice during the summer of 2005-June 10 at 5:15 p.m. and July 21 at 4:15 a.m. $E$. coli concentrations were not elevated at the Main Beach until two days after the discharge (June 12) that occurred on June $10\left(\mathrm{R}_{\mathrm{d}-1}\right.$ was $0 \mathrm{in}$. at the airport gage and $0.83 \mathrm{in}$. at the John Marshall gage for June 11). In contrast, on July 21, Main Beach and Middle Beach E. coli concentrations were quickly elevated in response to the overflow $\left(\mathrm{R}_{\mathrm{d}-1}\right.$ was $0.77 \mathrm{in}$. at the airport gage and 1.15 in. at the John Marshall gage for July 21). On June 10 and 11, there were no waves or noticeable currents, whereas on June 12 and July 21, wave heights were $1 \mathrm{ft}$ with northwesterly and southerly currents, respectively. This pattern indicates that currents and waves may play a significant role in delivering nearshore contaminants to the Main Beach.

\section{Shallow Ground Water}

Shallow ground water was sampled at Edgewater to understand the relations of $E$. coli concentrations in shallow ground water in foreshore sands to those in lake water: Is shallow ground water a source of E. coli to the lake, is the lake providing a source of $E$. coli to shallow ground water, or is it a combination of both mechanisms? Additionally, are the backshore sands (sands not infiltrated by lake water during the season) and areas upgradient from the beach a source of $E$. coli to the beach? What is the role of local rainfall, lake level, and wave action in affecting $E$. coli concentrations in shallow ground water? These questions were addressed by determining the direction of ground-water flow (as measured by hydraulic gradients), by determining concentrations of $E$. coli in ground water and the lake simultaneously, and by examining environmental and meteorological data.

The hydraulic gradient is the difference in hydraulic head between two points divided by the distance between the points. If these differences are measured in a nearly horizontal plane (on a well at distance from another at a similar elevation), this is generally considered the horizontal hydraulic gradient. If the differences are measured vertically (between a shallow and deep piezometer at nearly the same location), it is the vertical hydraulic gradient. The hydraulic gradient is expressed as a dimensionless quantity and is used to determine flow direction.

Ground water was sampled on June 30 and July 28-29, 2004, at the east location of Edgewater (fig. $1 B$ ) to determine shallow horizontal hydraulic gradients and spatial patterns of E. coli concentrations in shallow ground water in foreshore and backshore sands. Measured water levels, in all instances, showed that shallow ground-water flow was toward the lake (fig. 7), although slight variations in the July water levels indicated that wave action may reverse the gradients less than $10 \mathrm{ft}$ inland from the edge of water ("near foreshore area") (fig. $7 B$ ). Concentrations of $E$. coli in piezometers ranged from $<1$ to $400 \mathrm{MPN} / 100 \mathrm{~mL}$. Concentrations of $E$. coli in lake-water samples in the two studies ranged from 17 to $190 \mathrm{CFU} / 100 \mathrm{~mL}$. The highest concentration of $E$. coli was found $50 \mathrm{ft}$ inland from the edge of water in June. In July, the highest concentrations were found in the near foreshore area. The higher random concentration in backshore sands in June indicates a possible source of $E$. coli inland from the beach; the high concentrations in the near foreshore in July indicate that interactions between the lake and shallow ground water may contribute to high concentrations of E. coli.

Additional short-term ground-water studies were done June 23 and July 20-21, 2005, at the west location of Edgewater (fig. $1 B$ ) to confirm the horizontal hydraulic gradients measured in 2004, determine vertical hydraulic gradients, and identify spatial patterns of $E$. coli in the near foreshore area. Weather conditions were different during the two studies done in 2005. On June 23, wave heights were measured as $1.5 \mathrm{ft}$, and the area received no rain $\left(\mathrm{R}_{\mathrm{d}-1}=0\right.$ in. $)$ at the airport and John Marshall gages. On July 20, wave heights were measured at $0.42 \mathrm{ft}$ with no rain at both gages; on July 21 , wave heights were measured at $1.0 \mathrm{ft}, \mathrm{R}_{\mathrm{d}-1}$ was 0.76 and $1.15 \mathrm{in}$. at the airport and John Marshall gages, respectively, and the Edgewater outfall discharged.

During both 2005 studies, temporal water-level measurements confirmed that the general horizontal hydraulic gradient was towards the lake; however, as in 2004, near-foreshore gradients were reversed at least once during each day (fig. 8). Vertical hydraulic gradients were assessed with shallow $(\approx 0.5 \mathrm{ft})$ and deep $(\approx 3 \mathrm{ft})$ piezometer pairs installed $6 \mathrm{ft}$ inland from the edge of water and from lakebed piezometers (gradient differences are not always visible on fig. 8, because the differences are very small). Vertical hydraulic gradients were shifting and variable in 2005. On June 23, the morning waterlevel measurements in inland piezometers indicated a slight upward gradient $(0.03 \mathrm{ft} / \mathrm{ft})$; noon and afternoon measurements showed a downward gradient $(0.07$ and $0.01 \mathrm{ft} / \mathrm{ft}$, respectively). Also in June, data from the lakebed piezometer showed that vertical hydraulic gradients between the lake and shallow lake bottom were always upward (0.14-0.3 ft/ft). In contrast, during July, inland vertical hydraulic gradients were always downward, and the vertical hydraulic gradients between the lake and lakebed piezometer were variable and ranged from downward $(0.07 \mathrm{ft} / \mathrm{ft})$ to upward $(0.13 \mathrm{ft} / \mathrm{ft})$. 
$\perp \exists \exists \exists \mathrm{NI} ` \perp H 9 I \exists H \exists \wedge \forall M$
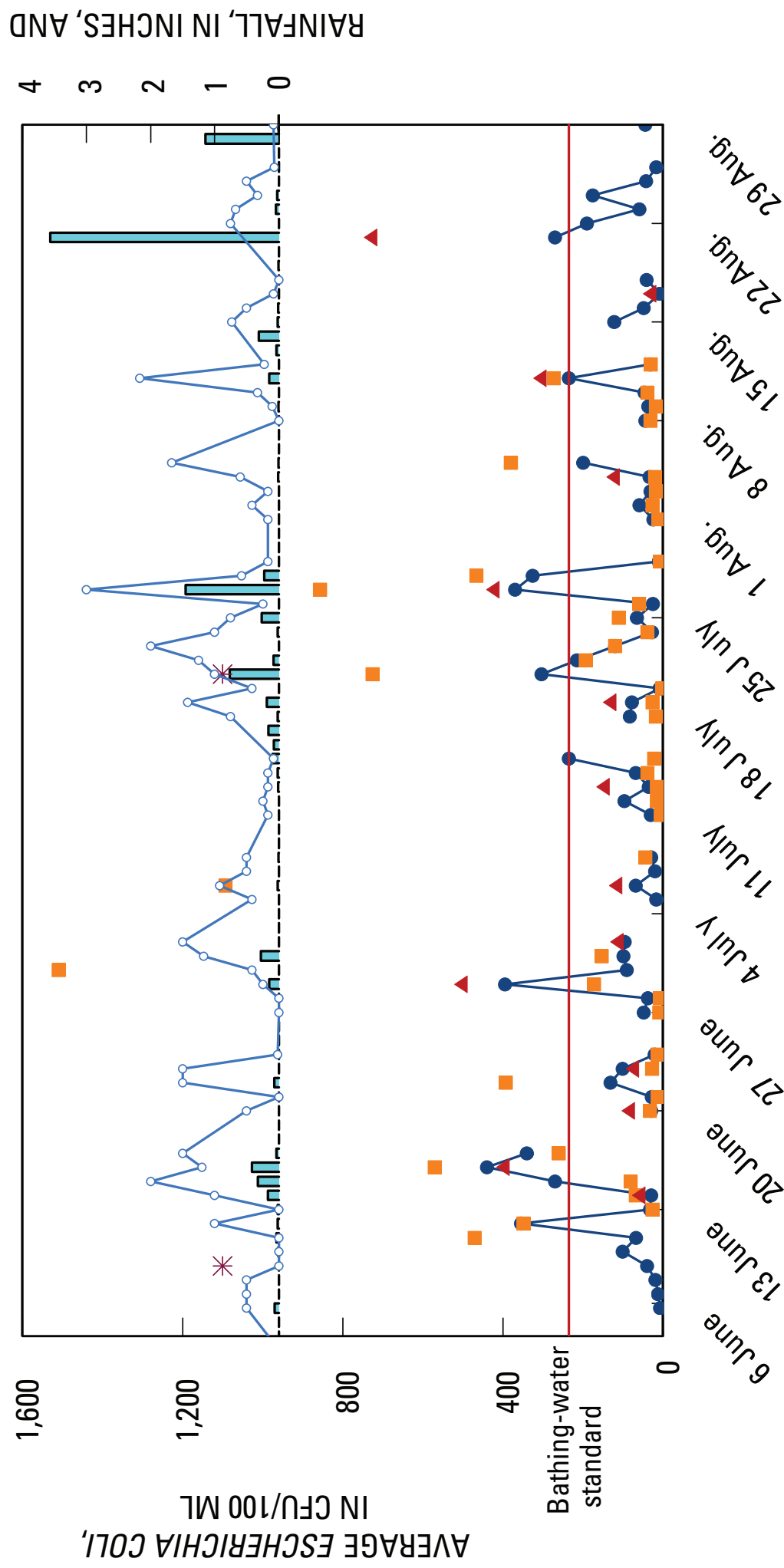

동

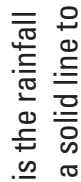

高

b)

늉

돈 운

을 엉

응 은

$b_{v_{1}}$

ذِ

范芒递

s)

वे

후 을 음

山'

임

U⿺辶万人

क क \&

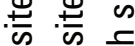

I/n

등

赵

竍崖

$\infty \infty$

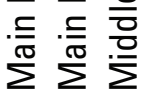

$\pi / 2$

$\pi / n$

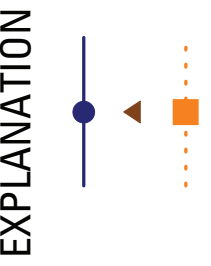

宊

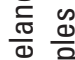

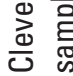

迹

莎

흉

sic

范

ब

更

.

垔 $\sum^{\pi}$

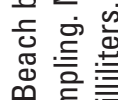

需

흥

$\sum_{0}^{0}$

它

.

$\sum^{\pi}$

世<smiles>[Te]=[Te]</smiles>

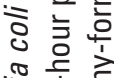

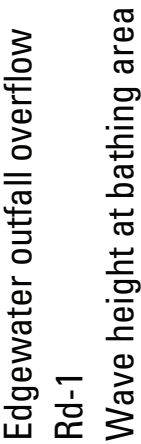

范定

ब。

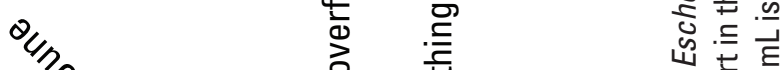

능응

象紊合

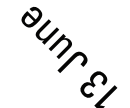

을 즌

产

ป 든

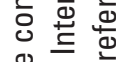

果

㐘

安 오윯

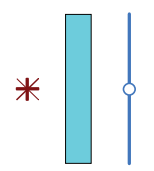

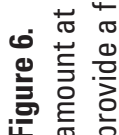



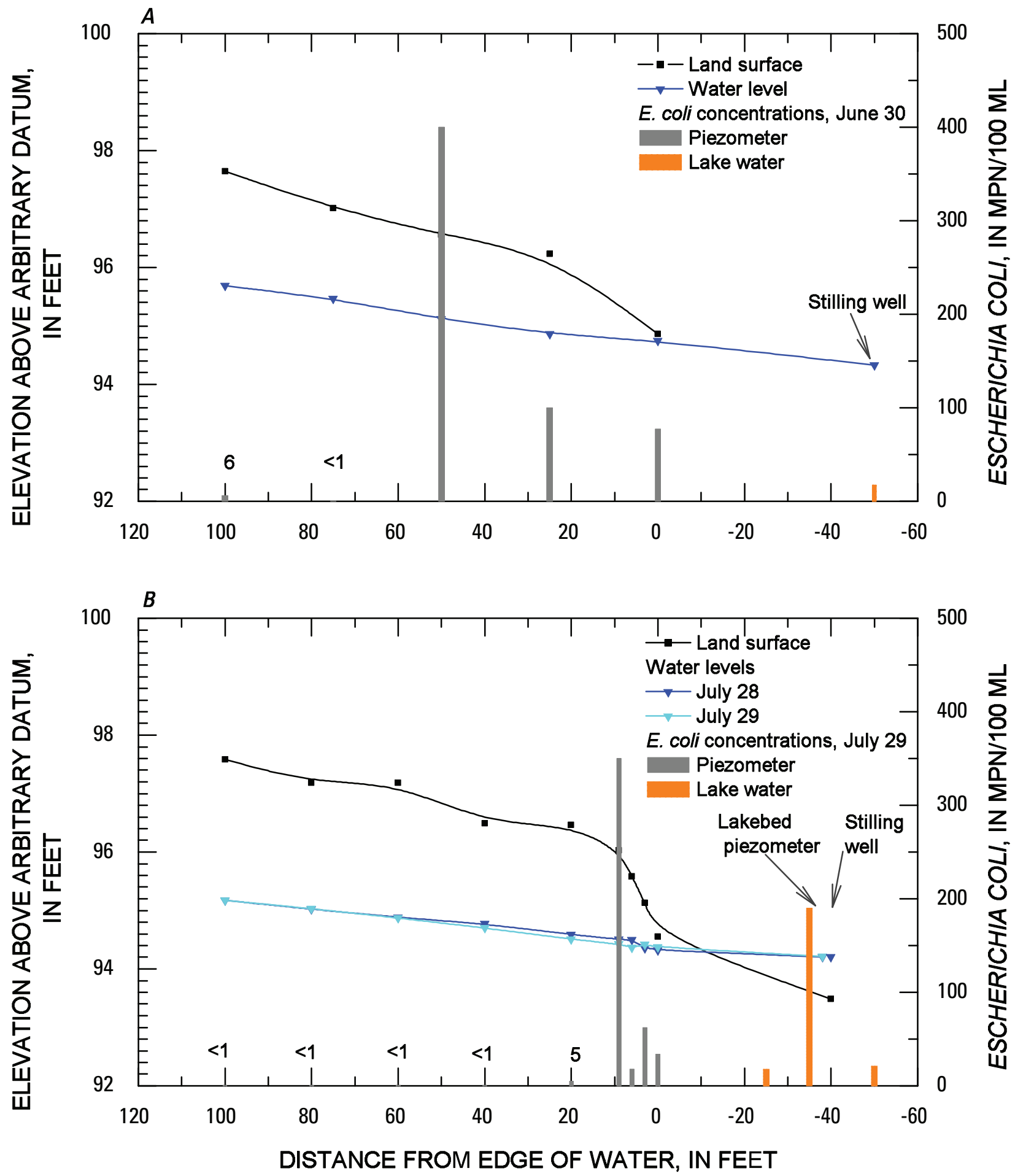

Figure 7. Land surface, water levels, and Escherichia coli (E. coli) concentrations in shallow ground water and lake water at the east sampling location at Edgewater, Cleveland, Ohio, 2004, in $A$, June, and $B$, July. (MPN/100 mL is the most probable number per 100 milliliters; $E$. coli concentrations not visually apparent are written numerically.) 

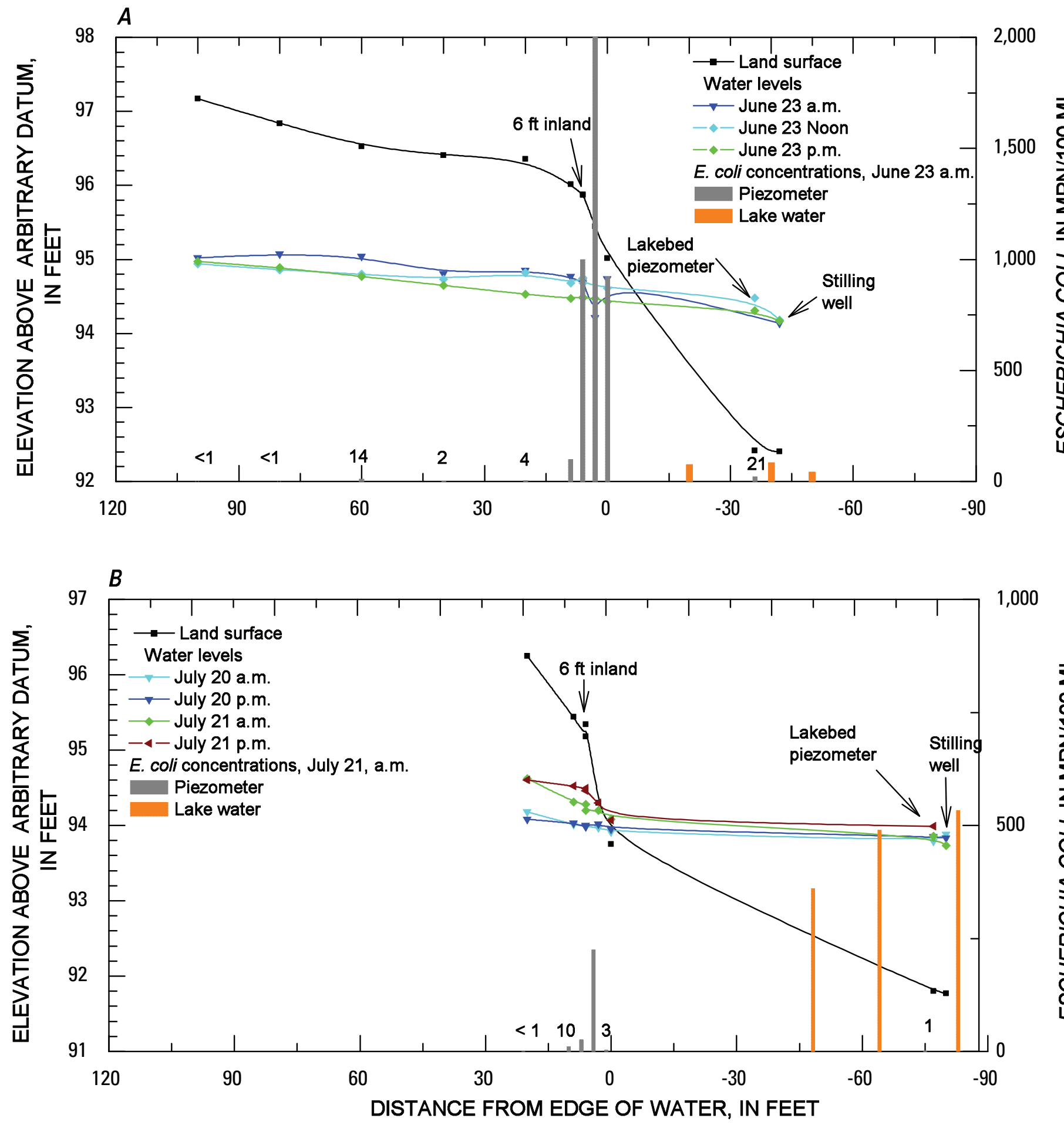

Figure 8. Land surface, water levels, and Escherichia coli (E. coli) concentrations in shallow ground water and lake water at the west sampling location at Edgewater, Cleveland, Ohio, 2005, in $A$, June, and $B$, July. (Piezometer 6 feet inland is an average of shallow and deep E. coli concentrations. Although E. coli concentrations were measured three times in July, one sampling is shown as an example for simplicity. MPN/100 $\mathrm{mL}$ is the most probable number per 100 milliliters.) 
Concentrations of $E$. coli in piezometers ranged from $<1$ to 2,000 and from $<1$ to $225 \mathrm{MPN} / 100 \mathrm{~mL}$ in June and July, 2005 , respectively. The highest concentrations of $E$. coli in both June and July in piezometers were found in the near foreshore area; the highest $E$. coli concentration further inland than $10 \mathrm{ft}$ was found in June 2005 at $60 \mathrm{ft}$ inland (14 MPN/100 mL; fig. 8A). In June 2005, E. coli concentrations were higher in piezometer samples than in lake-water samples (fig. 8A). In contrast, in July 2005, E. coli concentrations from lake-water samples were higher than concentrations found in piezometer samples (fig. 8B). E. coli concentrations from the lake were always higher than concentrations found in lakebed piezometers.

A monthlong ground-water study was done late summer 2005 at the west location at Edgewater to better define temporal relations between $E$. coli concentrations in the near foreshore area and the lake (fig. 9). The piezometers were placed at $6 \mathrm{ft}$ and $9 \mathrm{ft}$ from the edge of water on August 16. The piezometer originally placed $6 \mathrm{ft}$ from the edge of water was more than $25 \mathrm{ft}$ from the edge of water after August 30, owing to seasonal lake-level decline; the piezometer originally placed $9 \mathrm{ft}$ from the edge of water was dry after August 30 (fig. 9A).

During this study, data were collected after two heavy rain events-August 21 and 31. After receiving 3.56 in. of $\mathrm{R}_{\mathrm{d}-1}$ on August 21, concentrations of $E$. coli in both piezometers increased to $>2,400 \mathrm{MPN} / 100 \mathrm{~mL}$ on August 22, whereas the lake $E$. coli concentration increased to only $220 \mathrm{MPN} / 100 \mathrm{~mL}$. The highest $E$. coli concentration (6,900 MPN/100 mL) was found in the 6-ft-inland piezometer on August 23. This delayed increase of $E$. coli concentrations may have been in response to the high waves that occurred on August 22 but did not occur on August 21. The high waves may have accelerated infiltration of surface $E$. coli into beach sands; the distance to the edge of water from the 6-ft inland piezometer was only $7-8 \mathrm{ft}$. The long antecedent dry period before August 21 also may have contributed to elevated $E$. coli concentrations. In contrast, on September 1 after 2.39 in. of $\mathrm{R}_{\mathrm{d}-1}$ on August 31, the piezometer E. coli concentration remained low ( $8 \mathrm{MPN} / 100 \mathrm{~mL}$ ) while the lake $E$. coli concentration increased to 1,400 MPN/100 mL. From August 31 to September 2, wave heights were elevated; however, the distance to the edge of water $(>25 \mathrm{ft})$ may have diminished any influence from the waves; a short antecedent dry period ( $<3$ days) may have also contributed to low E. coli concentrations in shallow ground water.

During the monthlong ground-water study, E. coli concentrations from shallow ground water generally decreased as the distance from the piezometers to the lake (edge of water) increased (fig. 9A). Overall, lake E. coli concentrations remained about the same or increased slightly during the sampling period. Lake level decreased about $0.5 \mathrm{ft}$ during this period, whereas water levels in the piezometers fluctuated but were at the same level at the end as the beginning of the study (fig. 9B). The decrease in lake levels with steady water levels in piezometers suggests that local precipitation and infiltration maintain the hydraulic head in shallow ground water in beach sands and that regionwide seasonal precipitation affects lake levels.

\section{Lakeshore}

At Lakeshore, sediment samples were collected to determine the potential for storage of $E$. coli in lakebed sediments from nearshore lake and bathing-area sites and in sediments from the gravel parking lot. Nearshore lake and bathing-area water samples were collected to identify potential origins of fecal contamination along the shoreline and west of Pinney Dock (fig. 2).

\section{Sediments}

Concentrations of $E$. coli in 29 bed sediment samples collected at bathing-area sites (sites A-C) ranged from 8 to $>500 \mathrm{CFU} / \mathrm{g}_{\mathrm{DW}}$ sediment (table 1). Among bathing-area sites, the median concentration was highest at site B, although statistically significant differences were not found between sites (ANOVA, data not shown). At nearshore lake sites (sites E-L), median concentrations of $E$. coli in bed sediments were highest at sites I and J. E. coli concentrations in 12 parking-lot sediment samples at four sites were high and variable, ranging from 440 to $20,000 \mathrm{CFU} / \mathrm{g}_{\mathrm{DW}}$ sediment (table 1).

\section{Nearshore Lake and Bathing Areas}

Patterns of $E$. coli concentrations in water at nearshore lake and bathing-water sites are shown for three days in 2004 with different antecedent rainfall amounts (fig. 10). During dry conditions (fig. 10A, June 24), samples were collected at four nearshore lake and two bathing-area sites; the $E$. coli concentration was above the standard at site $\mathrm{F}$ and below at all other sites. After the first sampling, additional nearshore lake sites and a central bathing-area site were added to the sampling scheme to better characterize spatial patterns. On a day with a moderate amount of $\mathrm{R}_{\mathrm{d}-1}$ (fig. $10 \mathrm{~B}$, August 18), E. coli concentrations were near or above the bathing-water standard at site $\mathrm{J}$ and at bathing-water sites (A-C). On a day with heavy Rw72 (fig. 10C, July 14), E. coli concentrations were very high at bathing-water sites and considerably lower at other nearshore lake sites. E. coli concentrations in water were low during the three days sampled at sites I, K, and L, which are further from the shoreline than the other nearshore lake sites (fig. 2).

Physical evidence obtained on July 12, 2004, showed that runoff from the gravel parking lot caused degradation of water quality at the beach. On that morning, it rained 0.68 in. from 6 to 8 a.m. Flowing discharge was observed from a pipe draining the parking lot to the beach at site B (fig. 11). The E. coli concentration from the parking-lot drain was 26,000 CFU/100 mL. 

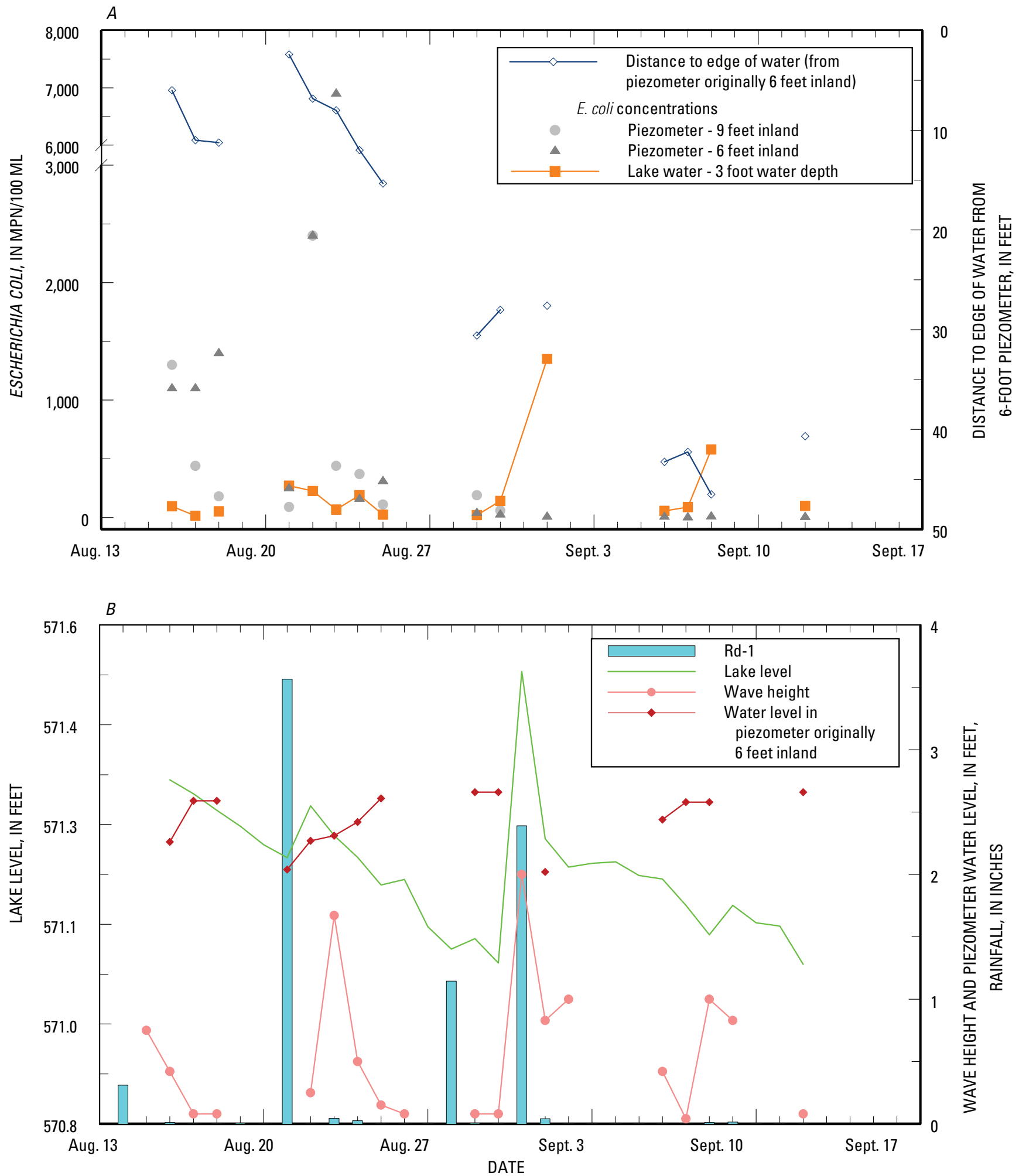

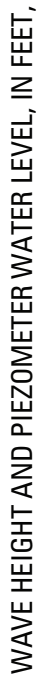

Figure 9. Escherichia coli (E. coli) concentrations in shallow ground water and lake water at the west sampling location, Edgewater, Cleveland, Ohio, 2005; associated with $A$, distance to edge of water; and $B, \mathrm{R}_{\mathrm{d}-1}$, lake level, wave height, and the water level in the piezometer 6 feet inland. (MPN/100 mL is the most probable number per 100 milliliters; $R_{d-1}$ is the rainfall amount at Hopkins International Airport in the 24-hour period preceding sampling; lake-level data were obtained from the National Oceanic and Atmospheric Administration station in Cleveland, Ohio; connecting lines are included to provide a point of reference.) 
Table 1. Escherichia coli concentrations in bed and parking-lot sediments in bathing-area, nearshore, and parking-lot sites at Lakeshore, Ashtabula, Ohio, 2004 and 2005.

$\left[\mathrm{MPN} / \mathrm{g}_{\mathrm{dw}}\right.$, most probable number per gram dry weight]

\begin{tabular}{|c|c|c|c|c|c|}
\hline \multirow[b]{2}{*}{ Site ID } & \multirow[b]{2}{*}{ Site description } & \multirow[b]{2}{*}{$\begin{array}{l}\text { Number of } \\
\text { samples }\end{array}$} & \multicolumn{3}{|c|}{ Escherichia coli, in MPN/g $\mathrm{g}_{\mathrm{dw}}$ sediment } \\
\hline & & & Minimum & Maximum & Median \\
\hline A & East & 11 & 14 & 320 & 63 \\
\hline $\mathrm{B}$ & Central & 7 & 8 & $>500$ & 120 \\
\hline \multicolumn{6}{|c|}{ Nearshore } \\
\hline $\mathrm{E}$ & West of beach groin & 3 & 20 & 200 & 160 \\
\hline $\mathrm{F}$ & $\begin{array}{l}\text { In front of pavilion, } \\
3 \text { foot depth }\end{array}$ & 1 & 8 & 8 & 8 \\
\hline I & West side of west groin & 3 & 200 & $>510$ & 490 \\
\hline $\mathrm{J}$ & Boat ramp & 3 & 470 & 1,200 & 470 \\
\hline $\mathrm{K}$ & Center point & 2 & 16 & 25 & 20 \\
\hline $\mathrm{L}$ & Pinney Dock & 3 & 59 & 170 & 59 \\
\hline \multicolumn{6}{|c|}{ Parking lot } \\
\hline AA & Northwest corner & 3 & 1,900 & 2,700 & 2,500 \\
\hline $\mathrm{BB}$ & West side & 3 & 920 & 8,200 & 3,200 \\
\hline $\mathrm{CC}$ & East side & 3 & 1,400 & 11,000 & 3,700 \\
\hline DD & Southwest corner & 3 & 440 & 20,000 & 2,000 \\
\hline
\end{tabular}

In 2005, spatial sampling was done on 12 days at sites that had high E. coli concentrations in 2004 and that were accessible from the shoreline; these included bathing-water sites and sites F, H, and J (fig. 2). E. coli concentrations were above the bathing-water standard at sites $\mathrm{F}, \mathrm{H}$, and $\mathrm{J}$ on 3 , 6, and 10 days, respectively (fig. 12). The three days when $E$. coli exceeded the standard at site F were associated with rainfall. In contrast, the exceedance at site F in 2004 was on a dry day (fig. 10). Runoff from the pavilion roof may have contributed to high E. coli concentrations in 2005 at site F. At sites $\mathrm{H}$ and $\mathrm{J}$, elevated $E$. coli concentrations were often associated with local rainfall, but not always.

\section{Multiple Antibiotic Resistance Indices of Escherichia coli Isolates and Presence of Human Markers}

Microbial source tracking methods were used to help better interpret spatial findings and determine whether sources of fecal contamination at Edgewater and Lakeshore were of human or nonhuman origin. MAR results were used as the first level of testing to distinguish between wastewater (representing human) and waterfowl sources of E. coli. A positive result for the Bacteroides and (or) the enterococcus human marker provided corroborating evidence of human fecal contamination; a negative result of both markers indicated that the markers were not found but did not preclude the possibility of human fecal contamination.

Because spreading of colonies on MAR plates from well to well was a common problem, procedures were developed to consistently identify antibiotic resistance and obtain the most useable data possible. A plate was discarded if more than onehalf the plate was affected by spreading colonies. If a colony spread out on a small area of a plate (less than five wells) and technicians were able to discern the original well of the spreader, it was coded as one resistant colony for that area. If a colony spread out on a large area of the plate or technicians could not discern the original well of the spreader, all affected isolates were removed from the dataset. For antibiotics tested with two concentrations, the plate with the higher number of countable wells was used for MAR index calculations. 

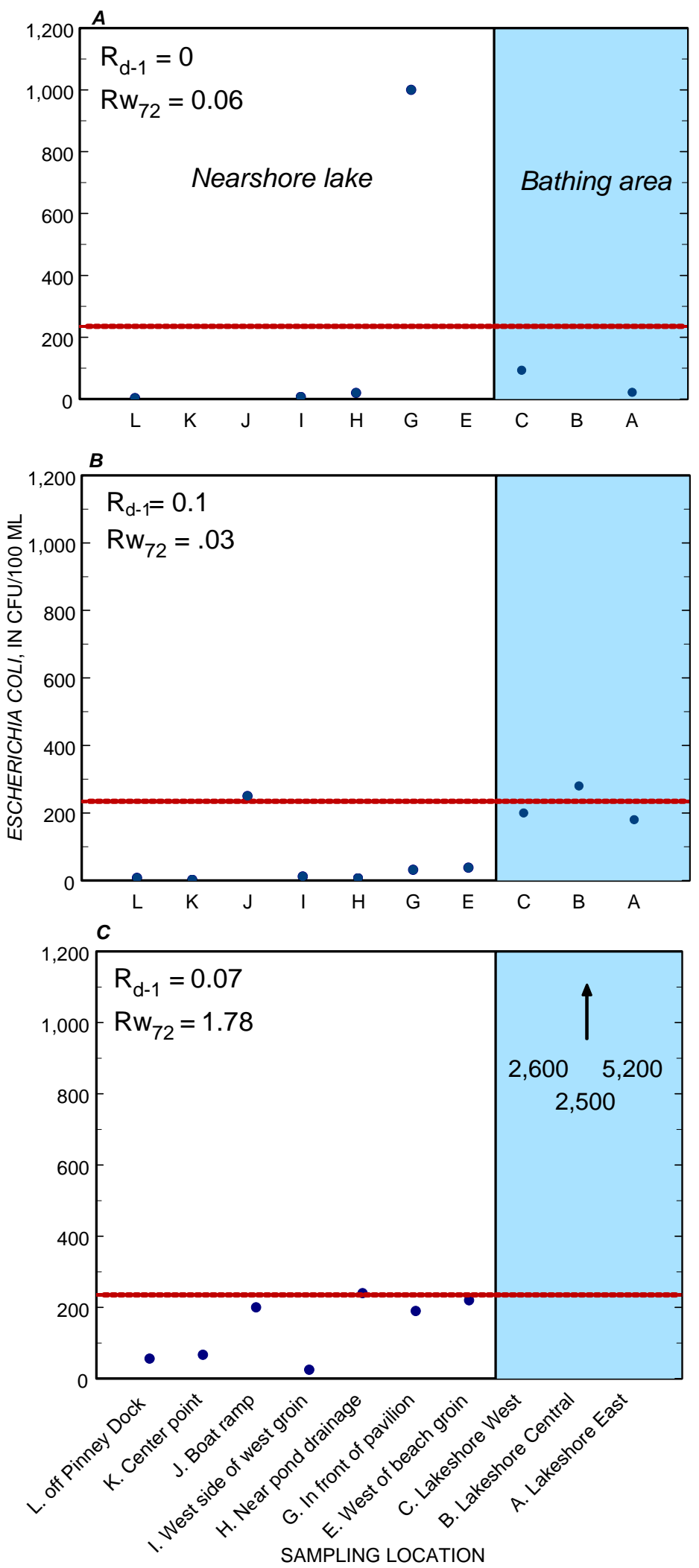

Figure 10. Concentrations of Escherichia coli in water collected at nearshore lake and bathing-water sites at Lakeshore, Ashtabula, Ohio, on three days in 2004. A, Dry conditions - June 24. B, Moderate rain - August 18. C, Heavy rain - July 14. $\left(\mathrm{R}_{\mathrm{d}-1}\right.$ is the rainfall amount from Ashtabula County Airport, in inches, in the 24-hour period preceding sampling. $\mathrm{Rw}_{72}$ is the weighted sum of rainfall amount in the 72-hour period preceding sampling, with the most recent rainfall receiving the most weight. The Ohio single-sample maximum bathing-water standard of 235 colony-forming units per 100 milliliters (CFU/100 mL) is indicated by dotted lines and is used as a point of reference.) 


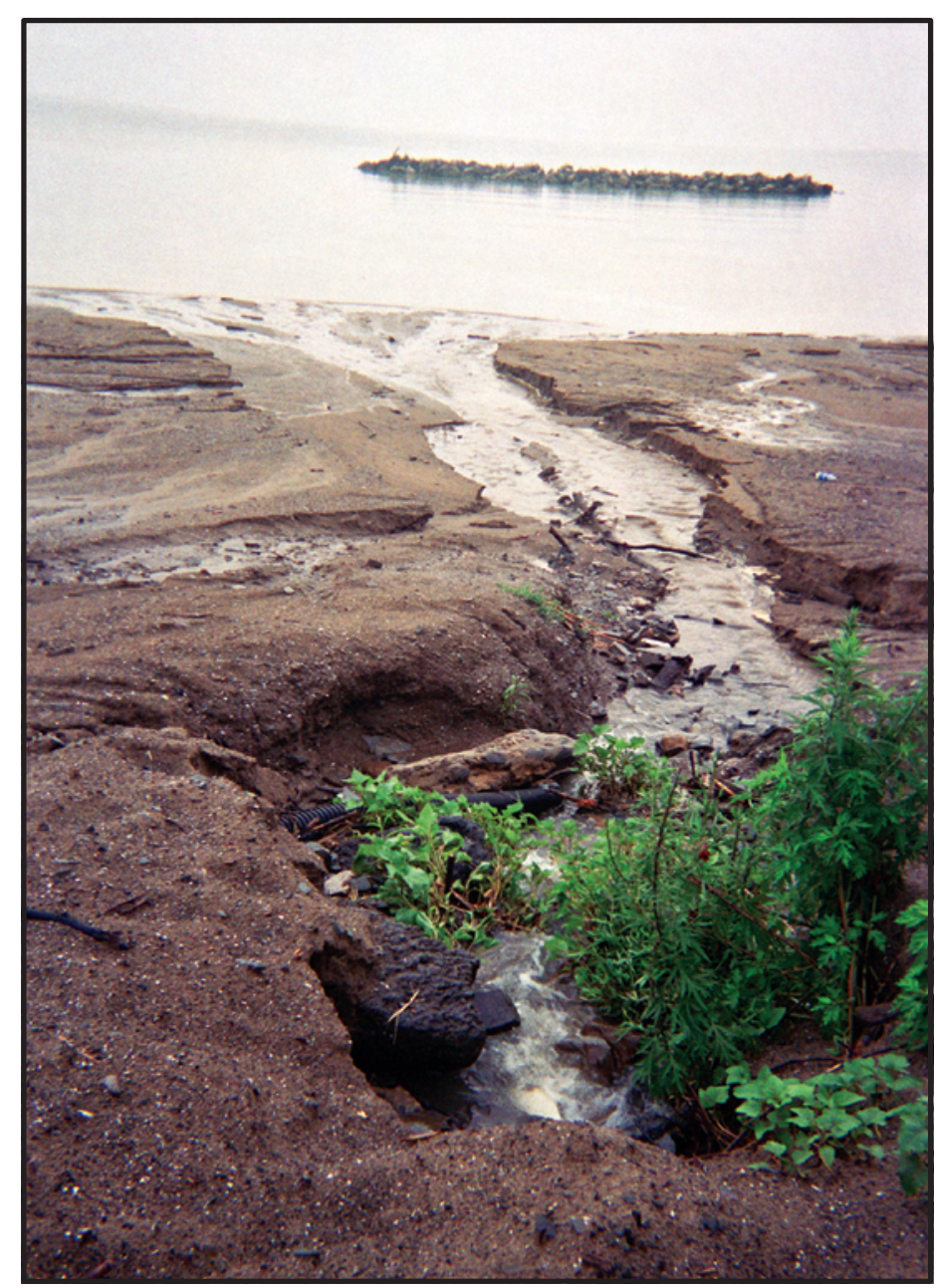

Figure 11. Stormwater runoff from a pipe draining the parking lot to the beach at Lakeshore, Ashtabula, Ohio, July 12, 2004. (Photograph by Timothy Roberts, U.S. Geological Survey)

MAR patterns and indices were different between the two source samples; bird feces and wastewater. MAR data from source samples on multiple sampling days were combined for each beach for data analysis. Out of 1,055 tests run on E. coli isolates from bird feces at Lakeshore, only 11 tests showed resistance: 7 to streptomycin, 1 to tetracycline, and 3 to ampicillin (data not shown). Similarly at Edgewater, out of 1,479 tests, 10 tests from bird feces showed resistance: 6 to streptomycin, 1 to tetracycline, and 3 to sulfathiazole. In contrast, in wastewater samples, 151 out of 1,004 tests at Lakeshore and 59 out of 655 tests at Edgewater showed resistance; resistant $E$. coli isolates were found for every antibiotic. (The dataset was smaller at Edgewater because plates were overgrown with spreading colonies on two dates.) For wastewater samples, individual antibiotic resistance indices ranged from 0.02 for nalidixic acid at Edgewater to 0.21 for streptomycin at Lakeshore (data not shown). At both beaches, overall indices for wastewater were about 10 times higher and significantly different from those found for bird feces (table 2).

Site-specific MAR indices for source samples were statistically compared to indices for environmental samples using
Chi-square analysis (table 2). At Edgewater, a definitive result was found for the bathing-water sample collected on September 1. In this sample, the index was significantly different from bird feces (chi-square $=67.0, \mathrm{p}=<0.0001$ ) but not from wastewater (chi-square $=0.91, p=0.3411$ ), indicating a predominant wastewater source. In the other four samples from Edgewater, the index was significantly different from both bird feces and wastewater. This result suggests mixed sources, although to varying degrees. For example, the bathing-water sample collected on July 13 may be more affected by wastewater than by bird feces, as shown by a lower chi-square and higher $p$ value for wastewater. At Lakeshore, definitive results indicating a bird source were found for the bathing-water sample collected on July 14 and for all samples collected on August 15. In these samples, the indices for environmental samples, ranging from 0.005 to 0.014 , were significantly different from wastewater, but not from bird feces. In the other four samples at Lakeshore, MAR indices suggested mixed sources. 
$\perp \exists \exists \exists \mathrm{NI} \perp \mathrm{HOI} \exists \mathrm{H} \exists \Lambda \forall M$

aNV 'S $\exists$ HONI NI 'ר $7 \forall J N I \forall Y$

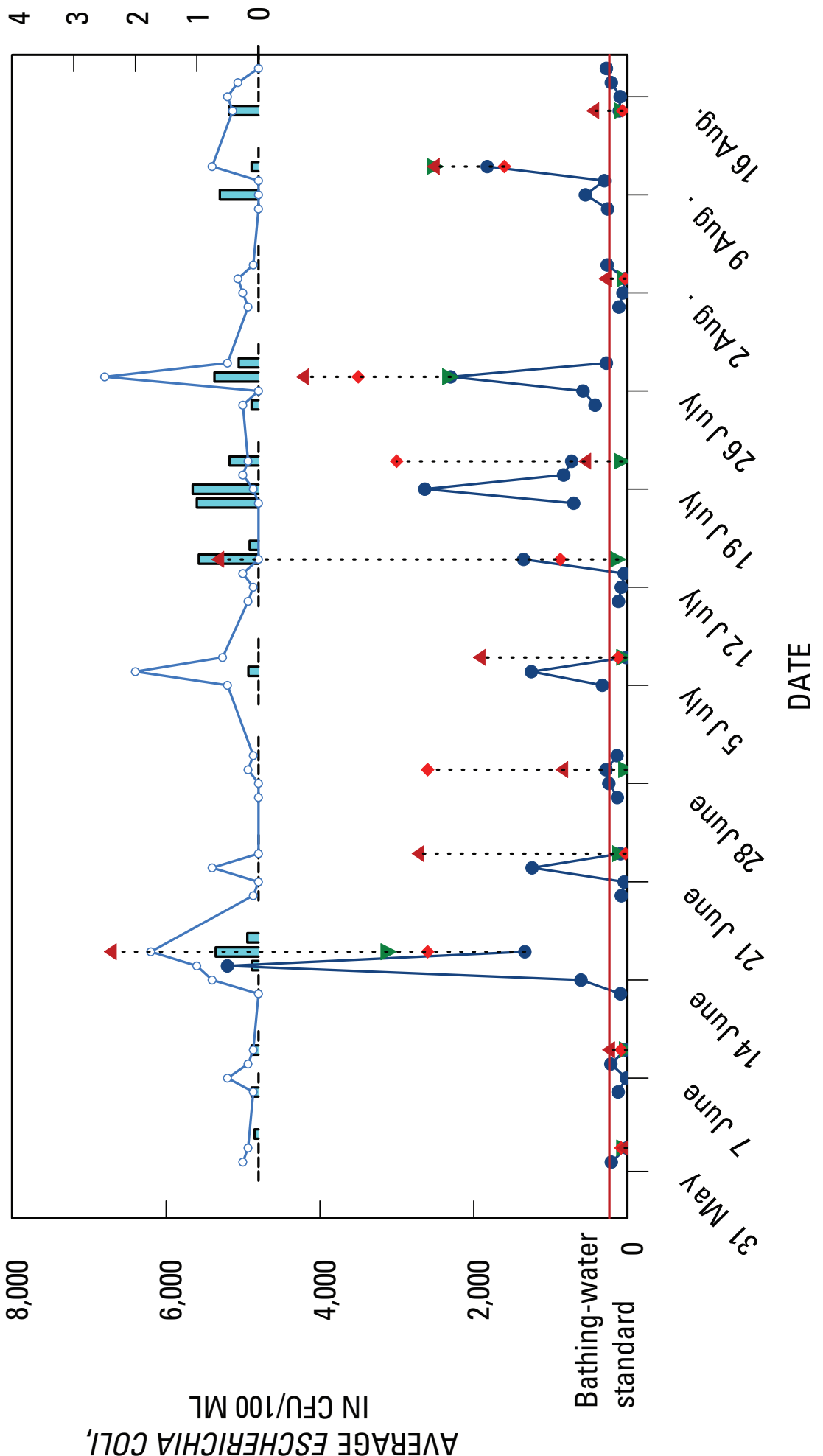

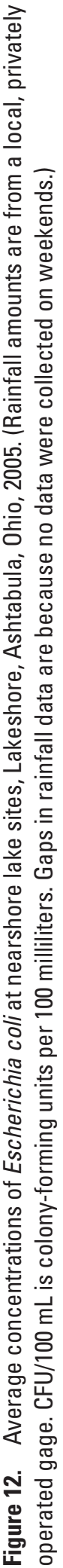


Table 2. Multiple antibiotic resistance (MAR) indices for samples collected at Edgewater and Lakeshore, 2005, and their relations to MAR indices of source samples.

[Chi-square is determined by use of contingency-table analysis; $p$ is the significance of the relation; MAR indices for source samples and results from contingency-table analysis between the two source samples are shown in bold text]

\begin{tabular}{|c|c|c|c|c|c|c|}
\hline \multirow[b]{3}{*}{ Date } & \multirow[b]{3}{*}{$\begin{array}{c}\text { Source or } \\
\text { environmental sample }\end{array}$} & \multirow[b]{3}{*}{ MAR index ${ }^{a}$} & \multicolumn{4}{|c|}{ Relation to source samples } \\
\hline & & & \multicolumn{2}{|c|}{ Wastewater } & \multicolumn{2}{|c|}{ Bird feces } \\
\hline & & & Chi-square & $p$ & Chi-square & $p$ \\
\hline \multicolumn{7}{|c|}{ EDGEWATER } \\
\hline & Wastewater source & 0.090 & & & 139.0 & $<0.0001$ \\
\hline & Bird feces source & .007 & & & & \\
\hline June 29 & Bathing water & .026 & 13.4 & 0.0003 & 9.4 & 0.0022 \\
\hline July 13 & Bathing water & .040 & 9.2 & .0024 & 25.8 & $<.0001$ \\
\hline Aug. 21 & Bathing water & .033 & 11.1 & .0009 & 16.2 & $<.0001$ \\
\hline Sept. 1 & Bathing water & .073 & .91 & .3411 & 67.0 & $<.0001$ \\
\hline Sept. 1 & Ground water & .032 & 5.8 & .0164 & 10.0 & .0015 \\
\hline \multicolumn{7}{|c|}{ LAKESHORE } \\
\hline & Wastewater source & .150 & & & 100.7 & $<.0001$ \\
\hline & Bird feces source & .010 & & & & \\
\hline June 28 & Bathing water & .032 & 30.4 & $<.0001$ & 7.6 & $<.0001$ \\
\hline July 14 & Bathing water & .010 & 60.6 & $<.0001$ & .02 & .8761 \\
\hline Aug. 15 & Bathing water & .014 & 47.8 & $<.0001$ & .33 & .5699 \\
\hline Aug. 15 & Parking Lot & .005 & 59.2 & $<.0001$ & .84 & .3605 \\
\hline Aug. 15 & Site N & .005 & 63.9 & $<.0001$ & 1.04 & .3093 \\
\hline Sept. 1 & Bathing water & .056 & 23.5 & $<.0001$ & 26.5 & $<.0001$ \\
\hline Sept. 1 & Parking Lot & .045 & 28.9 & $<.0001$ & 17.1 & $<.0001$ \\
\hline Sept. 1 & Site I & .041 & 31.7 & $<.0001$ & 14.6 & $<.0001$ \\
\hline
\end{tabular}

aThe MAR index is calculated as the number of resistant isolates/number of antibiotics tested X total isolates tested.

Human markers for Bacteroides and enterococci were used in conjunction with MAR indices as multiple lines of evidence (table 3). At Edgewater, both human markers were found on September 1 in bathing-water samples, further confirming the MAR results of predominantly wastewater sources. On September 1, the area received the remnants of Hurricane Katrina, including 3- to 5-ft wave heights and heavy Rw72; E. coli and enterococci concentrations were elevated. In all other samples at Edgewater, the MAR index indicated a mixed source, yet neither human marker was found. E. coli and enterococci concentrations were lower in these samples than those collected on September 1.

At Lakeshore, both human markers were found on July 14 in bathing water, yet the results from the MAR index indicated bird feces as a predominant source; E. coli and enterococci concentrations were elevated in this sample. In contrast, on August 15, results from MAR indexes and human markers were in agreement: human markers were not found in any samples, and the MAR indices were consistent with a bird fecal source. At site I on September 1, the Bacteroides marker was found, the enterococci marker was not found, and MAR indicated mixed sources. Parking-lot samples were determined to be from bird sources on August 15 and mixed sources on September 1 by use of the MAR index; the enterococci marker was not found. 


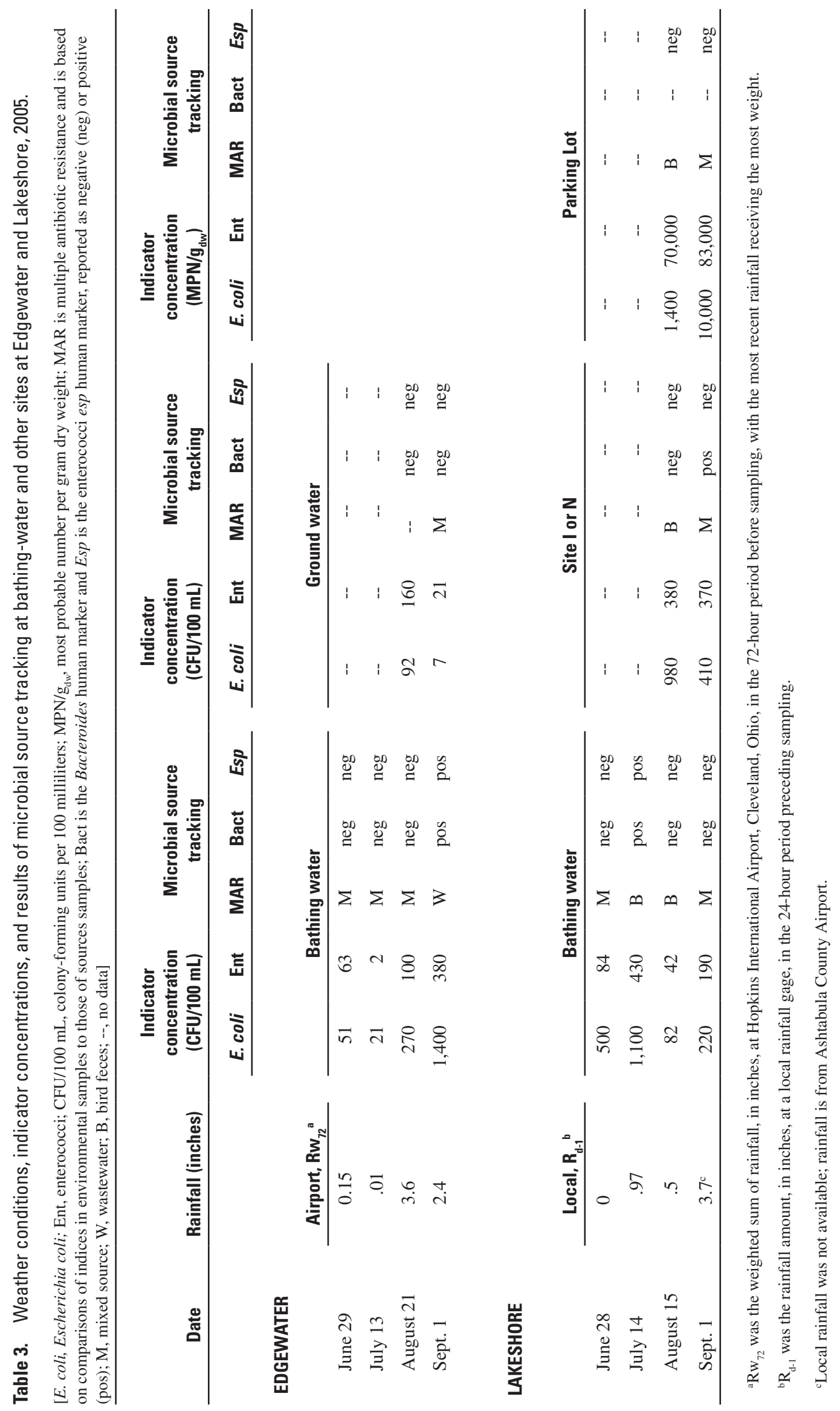




\section{Discussion and Conclusions}

A multiple-method approach was used to help identify sources of fecal contamination at two Lake Erie beaches: an urban beach (Edgewater) and a beach in a small city (Lakeshore). Sampling identified spatial patterns in E. coli concentrations and yielded information on the physical pathways of contamination. MST testing provided information on whether the source was from wastewater or bird feces and if a humanspecific marker was present; however, MST did not provide information on the pathways of contamination.

\section{Edgewater}

The first step at Edgewater was to identify the importance of remote sources of fecal contamination in this highly urbanized area. During 2003 and 2004, E. coli concentrations near the mouths of rivers and outfalls remote to the beach were elevated during wet conditions but generally decreased along transport pathways to the beach. Further, concentrations were lower in nearshore lake samples typically collected $150 \mathrm{ft}$ from the shoreline than in those collected within the bathing area at Edgewater, indicating a potential local source to the beach. Nearshore lake samples, however, were not collected at 3 -ft depths and similar proximities to the shoreline as bathingwater samples; nearshore lake samples collected closer to the shoreline are needed to strengthen the local-source hypothesis. Nevertheless, a transport pathway to the beach from nearshore lake sites with high $E$. coli concentrations was not evident, and it seems unlikely that fecal contamination would hug the shoreline and not be transported at least $150 \mathrm{ft}$ offshore. This line of thinking downgraded the importance of remote sources to the beach, and subsequent source-tracking efforts concentrated on the beach itself.

In 2005, E. coli concentrations were compared in Main and Middle Beach bathing-water samples at Edgewater. Elevated E. coli concentrations were generally associated with rainfall and (or) high waves; however, there were days when E. coli was elevated in the absence of rainfall or high waves. Samples collected at the Middle Beach had generally higher $E$. coli concentrations than those collected at the Main Beach. The different responses of $E$. coli concentrations on two days the outfall flowed in 2005 suggested that waves and currents may be important factors in transporting E. coli from the Middle to the Main Beach. Further, frequent elevated E. coli concentrations in the absence of a discharge at the Edgewater outfall indicated that outfall discharges were not a major source of fecal contamination at Edgewater. Because the Middle beach is not guarded, borders a wooded area, and tends to be visited by boaters and dog owners and not by swimmers, potential sources include the illegal discharge of wastes from boaters; wastes from dogs, stray cats, and wildlife; and resuspension of $E$. coli from lakebed sediments through the actions of jet skis, boats, and waves. The Middle beach also has the potential to receive stormwater from an abandoned storm sewer system.

Sources at the Middle Beach may not be the only ones contributing to elevated E. coli in the Main beach. In earlier studies (Francy and others, 2003), turbidity and wave heights were statistically related to $E$. coli concentrations, providing circumstantial evidence that resuspension of $E$. coli from lakebed sediments may be important at Edgewater. In the present study, samples collected at 1- and 2-ft water depths at the Main Beach had higher E. coli concentrations than those collected at 3 -ft water depths. This may be from resuspension of $E$. coli from lakebed sediments or from storage and accumulation of $E$. coli from shallow ground water in the foreshore area.

Short-term shallow ground-water studies at Edgewater in 2004 and 2005 showed that ground water generally flows toward the lake, with slight temporal reversals in flow in the near foreshore area, probably a result of ground-water response to wave action. An E. coli concentration peak at a seemingly random location in June 2004 showed the heterogeneity of $E$. coli concentrations in beach sands. This suggests a local surface source, such as feces from the large numbers of gulls that congregate on the beach. Infiltration of bird feces through sand with surface water from rainfall or high waves may be a mechanism of concentrating $E$. coli in shallow ground water. Because concentrations of $E$. coli generally declined with increasing distance inland from the lake, another inland source may be the interaction of the lake with shallow ground water in the near foreshore area; this interaction may sustain higher levels of $E$. coli in the shallow ground water close to the lake, even after lake $E$. coli concentrations decline. A monthlong study (August 16 through September 12, 2005) supported the hypothesis that the interaction of shallow ground water and waves is a mechanism of E. coli storage and accumulation; as the distance to the edge of water increased, E. coli concentrations in shallow ground water generally decreased. The monthlong study also supported the hypothesis that infiltration of precipitation and waves through beach sands is a likely mechanism of $E$. coli transport to ground water.

In other studies, investigators found that fecal-indicator bacteria were abundant in beach sands, may be a reservoir for enteric organisms, and may affect recreational water quality (Alm and others, 2003; Kinzelman and others, 2004a). It is well known that bacteria survive longer in sediments than in water because sediments provide a nutrient-rich environment and protection from sunlight inactivation and protozoan grazing (Alm and others, 2003; LaLiberte and Grimes, 1982). At a Lake Michigan beach frequented by large populations of seagulls, investigators found that deeper beach grooming practices without leveling resulted in lower E. coli concentrations in foreshore sands than shallow practices with leveling (Kinzelman and others, 2004b). The former practice helped to aerate the sand and allowed for exposure of bacteria to sunlight and predators. The investigators suggested that significant populations of seagulls contribute to the accumulation 
of $E$. coli in beach sands and that waves washing over beach sands could transport bacteria from sediments to lake waters as they recede. Investigators in the United Kingdom found that pathogenic species of Campylobacter were more prevalent in sand at beaches that did not meet the European Commission (EC) Bathing Water Directive than at beaches that met the Directive (Bolton and others, 1999). The EC Bathing Water Directive specifies the microbial standards for recreational waters in Europe. Their results indicated that sand may be acting as a natural filter leading to concentration of pathogens on areas of the beach used by the public and may be an important mechanism for reseeding of bathing water with pathogens.

A complicated scenario emerges at Edgewater-spatial patterns of $E$. coli indicated that local sources of fecal contamination were dominant; the Edgewater outfall was not a major source of fecal contamination; elevated $E$. coli concentrations were often associated with rainfall and (or) high waves, but not always; and elevated $E$. coli concentrations were found in shallow ground water, especially in the active near foreshore area. MST methods indicated that mixed sources were present (bird feces and wastewater) on all days sampled except for September 1, which was affected by atypical weather patterns associated with Hurricane Katrina. Human markers were found only on September 1, when the MAR index indicated a dominant wastewater source and bacterial indicator concentrations were high. Concentrations of bacterial indicators may have been too low to detect human markers on the other days when MAR indices indicated mixed sources. Scott and others (2005) proposed that the absence of the human enterococci marker could indicate a nonhuman source of contamination, but only in association with high counts of enterococci.

\section{Lakeshore}

At Lakeshore, low concentrations of E. coli at nearshore lake sites furthest from the shoreline indicated that fecal contamination was most likely of local origin. High concentrations of $E$. coli in water and sediments at several nearshore lake sites close to the shoreline showed that contamination was emanating from several points. Bathing-area bed sediments and the gravel parking-lot sediments appeared to be important reservoirs of E. coli; physical evidence confirmed that runoff from the gravel parking lot was an important contributor. A dry-weather source at site $\mathrm{F}$ (in front of the pavilion) caused high E. coli concentrations on one day in 2004 but not on the days sampled in 2005. Elevated concentrations of E. coli at sites $\mathrm{H}$ (near pond drainage) and $\mathrm{J}$ (boat ramp) indicated that sources of fecal contamination were concentrated in these areas in both dry and wet weather.

At Lakeshore bathing-water sites, MST results indicated mixed sources on three out of four days tested. On a day with moderate rainfall and elevated E. coli and enterococci concentrations (July 14), both human markers were found in bathing waters, yet the MAR index indicated bird feces as the dominant source. On another day (August 15) that received $0.5 \mathrm{in.}$ of local rainfall in past 24 hours and indicator concentrations were not elevated, results from MAR indexes and human markers were in agreement that bird feces was the dominant source. MAR indices indicated mixed or bird sources at sites I (west side of west groin) or N (east side of west groin) and at parking-lot sites. Both human markers are almost always found in sewage from a wastewater-treatment plant that serves large populations, but only the Bacteroides marker was consistently found in individual fecal samples (Troy Scott, Biological Consulting Services of N. Florida, Inc., oral commun., 2006). On September 1, the Bacteroides marker was found at site I, but not the enterococci marker. This suggests that the source of human fecal contamination may be from a small contributing population, such as one or more septic systems, and not from wastewater with a large contributing population.

\section{Using a Multiple-Method Approach to Source Tracking}

The studies at Edgewater and Lakeshore indicate that a multiple-method approach is needed to identify sources of fecal contamination at coastal beaches. These include (1) documenting the spatial variability of fecal contamination in the area and at the beach, (2) identifying the environmental and meteorological factors that affect indicator concentrations, and (3) applying multiple MST techniques to help understand earlier findings. This type of approach was used successfully to track sources of fecal contamination to a recreational area in southern California (Noble and others, 2006). Investigators found that levels of fecal-indicator bacteria were not discerning because they were consistent throughout the watershed. By adding other tools to the investigation, such as presence of human enterovirus and human-specific Bacteroides marker, researchers were able to identify the most important sources.

Birds are an important source of fecal contamination at Lake Erie beaches and elsewhere. Canadian researchers found a significant correlation $(r=0.88)$ between fecal-coliform concentrations and number of birds at bathing-beach locations on a spring-fed lake (Lévesque and others, 1993). When food was spread on the sand, the number of gulls on the beach and fecal-coliform concentrations in the water increased rapidly. In a Great Lakes study, high concentrations of $E$. coli $\left(10^{5}-10^{9} \mathrm{CFU} / \mathrm{g}\right)$ associated with gull feces suggested that gulls may be a major contributor to fecal contamination to beaches (Fogarty and others, 2003). Unfortunately, markers that indicate bird contamination are not available; for example, in one recent study, Fogarty and Voytek (2005) were unable to detect fecal contamination by avian species using Bacteroides markers.

Several MST methods are needed in order to help distinguish human from wildlife sources of fecal contamination at beaches. Studies should include both Bacteroides and enterococcus human markers to provide definitive evidence of a human source. However, the absence of either marker does not necessarily imply the absence of a human source of fecal 
contamination, especially when indicator concentrations are low. MAR indices can help to identify sources, even when indicator concentrations are low and human markers are not found. In a study of $E$. coli source isolates in southern Ontario, average MAR indices for human, livestock, and wildlife isolates were $0.1339,0.0966$, and 0.027 , respectively (Guan and others, 2002); these are similar to those found in sources at Lakeshore and Edgewater (table 2). This consistency between sites further illustrates the usefulness of MAR indices.

More work needs to be done during a variety of weather and wave conditions that combines spatial sampling with MST tools to better understand the sources of fecal contamination at Edgewater and Lakeshore. At Edgewater, additional days would need to be sampled, including days with high indicator concentrations and no rainfall or waves. A season-long shallow ground-water study that incorporates MST tools would help to further reveal the interactions between shallow ground water and lake water at Edgewater. At Lakeshore, more work needs to be done at nearshore lake sites that combines spatial sampling with MST and includes several consecutive days when $E$. coli concentrations are elevated during dry and wet weather.

\section{Summary}

Because of the complexity of coastal environments and the prevalence of nonpoint sources of fecal contamination, a multiple-method approach is practical for identifying sources of fecal contamination at coastal beaches. This approach was applied to two Lake Erie bathing beaches: Edgewater in Cleveland, Ohio, and Lakeshore in Ashtabula, Ohio. Steps included identifying spatial patterns of $E$. coli concentrations in each area, determining weather patterns that caused elevated E. coli, and applying microbial source tracking (MST) techniques to specific sites.

Edgewater and Lakeshore are popular recreational areas with beaches in a highly urbanized area and a small municipality, respectively. The beach at Edgewater is potentially affected by effluents from wastewater-treatment plants and septic systems, stormwater runoff, CSO's, and wildlife. Lakeshore is potentially affected by treated wastewater, septic systems, drainage from inland ponds, stormwater runoff from the park and parking lots, wildlife, and illegal discharges from boats. At Edgewater, spatial sampling for E. coli was done at bathing-area, nearshore lake, and shallow-ground-water sites during 2003-05. At Lakeshore, spatial sampling for $E$. coli was done at bathing, nearshore lake, and parking-lot sites in 2004 and 2005. Weather data were compiled from the nearest National Weather Service station at both beaches or from a local source, when available. Samples were collected for MST testing on four days during 2005. These included bird fecal samples and wastewater from local treatment plants as source samples from both beaches. Environmental samples for MST testing included bathing-water samples at both beaches; shal- low ground-water samples were collected at Edgewater and nearshore lake and parking-lot samples were also collected at Lakeshore. Three MST methods were used during this study: multiple antibiotic resistance (MAR) indexing of E. coli isolates and the presence of human-specific genetic markers within two types of bacteria, Bacteroides and enterococcus.

At Edgewater, spatial patterns of E. coli indicated that local sources of fecal contamination were dominant; the Edgewater outfall was not a major source of fecal contamination; elevated $E$. coli concentrations were often associated with rainfall and (or) high waves, but not always; and elevated $E$. coli concentrations were found in shallow ground water. $E$. coli concentrations near the mouths of rivers and outfalls remote to the beach were elevated during wet conditions, but concentrations decreased along transport pathways to the beach. In addition, concentrations of $E$. coli were lower in nearshore lake samples collected $150 \mathrm{ft}$ from the shoreline than in those collected within the bathing area. Further supporting the theory of local sources, samples collected within the bathing area at 1- and 2-ft water depths had higher E. coli concentrations than those collected at 3-ft water depths. Measured hydraulic gradients showed that shallow groundwater flow was generally towards the lake. E. coli concentrations were often elevated in shallow ground water in the near foreshore area and were occasionally elevated in random backshore locations. The interaction of the lake with shallow ground water in the near foreshore area may sustain higher levels of $E$. coli in the shallow ground water close to the lake, even after lake $E$. coli concentrations decline. The infiltration of bird feces through beach sands by precipitation and waves is also a likely mechanism of $E$. coli transport to ground water.

At Lakeshore, low concentrations of E. coli in the nearshore lake sites furthest from the shoreline indicated that fecal contamination was most likely of local origin. Spatial sampling at Lakeshore indicated elevated concentrations during wet and dry weather at bathing-area sites, in parking-lot sediments, and at nearshore lake sites at the boat ramp (site J) and near the pond drainage ( site $\mathrm{H}$ ); fecal contamination may therefore be emanating from several points along the shoreline. Actual physical evidence confirmed that runoff from the parking lot leads to the degradation of water quality at the beach.

MST samples were collected in 2005 to help interpret spatial findings and determine whether sources of fecal contamination were of human or nonhuman origin. MAR indices (number of resistant isolates / (number of antibiotics tested $\times$ total isolates tested)) were useful in distinguishing between bird feces and wastewater sources. MAR indices for bird feces were 0.007 and 0.010 at Edgewater and Ashtabula, respectively. At the same two beaches, MAR indices for wastewater (0.090 and 0.150) were about 10 times higher than those for bird feces. The results from MAR indices agreed with results from the two human-specific markers in some but not all of the samples tested. On one day at Edgewater, the MAR index of bathing-water samples indicated a wastewater source, and both Bacteroides and enterococci markers were found to 
corroborate this finding. Similarly, on one day at Lakeshore, the MAR index indicated a bird feces source, and no human markers were found in bathing-water samples. On three days at Edgewater and two days at Lakeshore, the MAR index indicated a mixed source, but neither marker was found; this may be because bacterial indicator concentrations were too low to detect a marker. Contradictory results were found at Lakeshore on one day when the MAR index in bathing-water samples indicated a predominant bird source, yet both human markers were found; E. coli and enterococci concentrations were elevated in bathing-water samples collected that day.

Multiple tools are needed to identify sources of fecal contamination at coastal beaches. Spatial sampling identified patterns in E. coli concentrations and yielded information on the physical pathways of contamination. MST methods provided information on whether the source was likely of human or nonhuman origin only; however, MST did not provide information on the pathways of contamination. As was found in other studies, waterfowl are an important source of fecal contamination at Lake Erie beaches. In order to distinguish between human and bird sources, several MST methods should be applied. Bacteroides and enterococci human markers provide evidence of a human source; however, the absence of both markers does not imply the absence of a human source, especially when indicator concentrations are low. MAR indices can help distinguish between human and waterfowl sources, even when indicator concentrations are low.

\section{Acknowledgments}

The authors acknowledge assistance from Dr. Sandra McLellan and her laboratory staff at the University of Wisconsin-Milwaukee in initiating the antibiotic resistance testing. Thanks are extended to Ron Golen at First Energy Corp. for providing rainfall amounts at Lakeshore. The authors thank Keith Linn, Elizabeth Toot-Levy, and Mark Citriglia of the Northeast Ohio Regional Sewer District and Brenda Stephens of the Ashtabula Township Park Commission for their valuable assistance in project planning and data interpretation. A special thanks goes to Timothy Roberts and Kenneth Frame, USGS summer interns, for all their hard work in collecting and analyzing samples.

\section{References Cited}

Alm, E.W., Burke, J., and Spain, A., 2003, Fecal indicator bacteria are abundant in wet sand at freshwater beaches: Water Research, v. 37, p. 3978-3982.
Bernhard, A.E., and Field, K.G., 2000a, Identification of nonpoint sources of fecal pollution in coastal waters by using host-specific 16S ribosomal DNA genetic markers from fecal anaerobes: Applied and Environmental Microbiology, v. 66 , no. 4, p. 1587-1594.

Bernhard, A.E., and Field, K.G., 2000b, A PCR assay to discriminate human and ruminant feces on the basis of host differences in Bacteroides-Prevotella genes encoding 16S rRNA: Applied and Environmental Microbiology, v. 66, no. 10 , p. $4571-4574$.

Boehm, A.B., Fuhrman, J.A., Mrše, R.D., and Grant, S.B., 2003, Tiered approach for identification of a human fecal pollution source at a recreational beach-Case study at Avalon Bay, Catalina Island, California: Environmental Science \& Technology, v. 37, p. 673-680.

Bolton, F.J., Surman, S.B., Martin, K., Wareing, D.R.A., and Humphrey, T.J., 1999, Presence of Campylobacter and Salmonella in sand from bathing beaches: Epidemiology and Infection, v. 122, p. 7-13.

Bower, P.A., Scopel, C.O., Jensen, E.T., Depas, M.M., and McLellan, S.L., 2005, Detection of genetic markers of fecal indicator bacteria in Lake Michigan and determination of their relationship to Escherichia coli densities using standard microbiological methods: Applied and Environmental Microbiology, v. 71, no. 12, p. 8305-8313.

Dick, L.K., Bernhard, A.E., Brodeur, T.J. , Santo Domingo, J.W., Simpson, J.M., Walters, S.P., and Field, K.G., 2005, Host distributions of uncultivated fecal Bacteroidales bacteria reveal genetic markers for fecal source identification: Applied and Environmental Microbiology, v. 71, p. 3184-91.

Fogarty, L.R., Haack, S.K., Wolcott, M.J., and Whitman, R.L., 2003, Abundance and characteristics of the recreational water quality indicator bacteria Escherichia coli and enterococci in gull faeces: Journal of Applied Microbiology, v. 94, p. $865-878$.

Fogarty, L.R., and Voytek, M.A., 2005, Comparison of Bacteroides-Prevotella $16 \mathrm{~S}$ rRNA genetic markers for fecal samples from different animal species: Applied and Environmental Microbiology: v. 71, p. 5999-6007.

Francy, D.S., Bushon, R.N., Brady, A.M.G., Kephart, C.M., and Stoeckel, D.M., 2005, Quality assurance/quality control manual for the Ohio Water Microbiology Laboratory, accessed at http://oh.water.usgs.gov/micro/lab.html\#qcm

Francy, D.S. and Darner, R.A., 1998, Factors affecting Escherichia coli concentrations at Lake Erie public bathing beaches: U.S. Geological Survey Water-Resources Investigations Report 98-4057, 71 p. 
Francy, D.S., Gifford, A.M., and Darner, R.A., 2003, Escherichia coli at Ohio bathing beaches-Distribution, sources, wastewater indicators, and predictive modeling: U.S. Geological Survey Water-Resources Investigations Report 02-4285, $120 \mathrm{p}$.

Francy, D.S., Struffolino, P., Brady, A.M.G., and Dwyer, D.F., 2005, A spatial, multivariable approach for identifying proximate sources of Escherichia coli to Maumee Bay, Lake Erie, Ohio: U.S. Geological Survey Open File Report 2005-1386, 20 p.

Guan, S., Xu, R., Chen, S., Odumeru, J., and Gyles, C., 2002, Development of a procedure for discriminating among Escherichia coli isolates from animal and human sources: Applied and Environmental Microbiology, v. 68, no. 6, p. 2690-2698.

Helsel, D.R., and Hirsch, R.M., 2002, Statistical methods in water resources: U.S. Geological Survey Techniques of Water-Resources Investigations, book 3, chap. A3, accessed March 2006 at http://pubs.er.usgs.gov/pubs/twri/twri04A3

Kaspar, C.W., Burgess, J.L., Knight, I.T., Colwell, R.R., 1990, Antibiotic resistance indexing of Escherichia coli to identify sources of fecal contamination in water: Canadian Journal of Microbiology, v. 36, p. 891-894.

Kinzelman, J., McLellan, S.L., Daniels, A.D., Cashin, S., Singh, A., Gradus, S., and Bagley, R., 2004a, Non-point source pollution-Determination of replication versus persistence of Escherichia coli in surface water and sediment with correlation of levels to readily measurable environmental parameters: Journal of Water and Health, v. 2, no. 2, p. 103-114.

Kinzelman, J., Pond, K.R., Longmaid, K.D., and Bagley, R.C., 2004b, The effect of two mechanical beach grooming strategies on Escherichia coli density in beach sand at a southwestern Lake Michigan beach: Aquatic Ecosystem Health \& Management, v. 7, no. 3, p. 425-432.

Krumperman, P.H., 1983, Multiple antibiotic resistance indexing of Escherichia coli to identify high-risk sources of fecal contamination of foods: Applied and Environmental Microbiology, v. 46, no. 1, p. 165-170.

LaLiberte, P., and Grimes, D.J., 1982, Survival of Escherichia coli in lake bottom sediment: Applied and Environmental Microbiology, v. 43, no. 3, p. 623-628.

Lévesque, B., Brousseau, P., Simard, P., Dewailly, E., Meisels, M., Ramsay, D., and Joly, J., 1993, Impact of the ring-billed gull on the microbiological quality of recreational water: Applied and Environmental Microbiology, v. 59, no. 4, p. 1228-1230.
Meays, C.L., Broersma, K., Nordin, R., and Mazumder, A., 2004, Source tracking fecal bacteria in water-A critical review of current methods: Journal of Environmental Management, v. 73, p. 71-79.

Myers, D.N., and Wilde, F.D., eds., 2003, Biological indicators ( $3 \mathrm{~d}$ ed.): U.S. Geological Survey Techniques of Water-Resources Investigations, book 9, chap. A7, accessed March 2006 at http://pubs.water.usgs.gov/twri9A7/

National Oceanic and Atmospheric Administration, 2005a, International Great Lakes Datum: Center for Operational Oceanographic Products and Services, accessed October 2005 at http://www.co-ops.nos.noaa.gov

National Oceanic and Atmospheric Administration, 2005b, National Virtual Data System-National Climatic Data Center: Asheville, N.C., accessed October 2004 and 2005 at http://nndc.noaa.gov/

Natural Resources Defense Council, 2005, Testing the waters 2005: New York, 280 p., accessed April 2006 at http://www.nrdc.org/water/oceans/ttw/titinx.asp

Noble, R.T., Griffith, J.F., Blackwood, A.D., Fuhrman, J.A., Gregory, J.B., Hernandez, X., Liang, X., Bera, A.A., and Schiff, K., 2006, Multitiered approach using quantitative PCR to track sources of fecal pollution affecting Santa Monica Bay, California: Applied and Environmental Microbiology, v. 72, no. 2, p. 1604-1612.

Ohio Department of Health, 2006, Bathing beach monitoring program: Columbus, Ohio, accessed May 2006 at http://www.odh.state.oh.us/odhPrograms/eh/bbeach/ beachmon.aspx

Ohio Environmental Protection Agency, 2003, Water use definitions and statewide criteria: Ohio Administrative Code, chap. 3745-1-07, p. 7 and 26, accessed April 2006 at http://www.epa.state.oh.us/dsw/rules/3745-1.html.

Parveen, S., Murphree, R.L., Edmiston, L., Kaspar, C.W., Portier, K.M., and Tamplin, M.L., 1997, Association of multiple-antibiotic-resistance profiles with point and nonpoint sources of Escherichia coli in Apalachicola Bay: Applied and Environmental Microbiology, v. 63, no. 7, p. 2607-2612.

Scott, T.M., Jenkins, T.M., Lukasik, J., and Rose, J.B., 2005, Potential use of a host associated molecular marker in Enterococcus faecium as an index of human fecal pollution: Environmental Science \& Technology, v. 39, p. 283-287.

U.S. Environmental Protection Agency, 2002a, Method 1603-Escherichia coli in water by membrane filtration using modified membrane-thermotolerant Escherichia coli agar: Washington, D.C., EPA 821-R-02-23, 9 p. 
U.S. Environmental Protection Agency, 2002b, Method 1600 - Enterococci in water by membrane filtration using membrane-enterococcus indoxyl- $\beta$-D-glucoside agar (mEI): Washington, D.C., EPA/821/R-02/022, 9 p.

U.S. Environmental Protection Agency, 2004, Water quality standards for coastal and Great Lakes recreational watersFinal rule: Federal Register 40 CFR Part 131, v. 69, no. 220, p. 67224-67226.
Webster, L.F., Thompson, B.C., Fulton, M.H., Chestnut, D.E., Van Dolah, R.F., Leight, A.K., and Scott, G.I., 2004, Identification of sources of Escherichia coli in South Carolina estuaries using antibiotic resistance analysis: Journal of Experiment Marine Biology, v. 298, p. 179-195. 